\title{
Dividend policy of Indonesian listed firms: The role of families and the state
}

\author{
Meryem Duygun \\ Business School, University of Nottingham, UK \\ E-mail: Meryem.Duygun@nottingham.ac.uk
}

Yilmaz Guney*

Business School, University of Hull, UK

E-mail: y.guney@hull.ac.uk

\begin{abstract}
Abdul Moin
Graduate School, Faculty of Economics, Universitas Islam Indonesia, Indonesia

E-mail: abdul.moin@uii.ac.id
\end{abstract}

Citation : Duygun M, Guney Y and Moin A. (2018). Dividend policy of Indonesian listed firms: the role of families and the state. Economic Modelling, volume, pp.

DOI: https://doi.org/10.1016/j.econmod.2018.07.007

(c) 2018. This manuscript version is made available under the CC-BY-NC-ND 4.0 license http:// creativecommons.org/licenses/by-nc-nd/4.0/

*Correspondence to: Yilmaz Guney, Business School, University of Hull, HU6 7RX, Hull, U.K. E-mail: y.guney@hull.ac.uk. Tel: (+44)(0) 148246 3079. Fax: (+44)(0) 1482463492.

\section{Acknowledgements:}

The authors would like to thank Sushanta Mallick (the editor), three anonymous referees, Brian Lucey, Robert Hudson and the participants of the 2015 Annual Conference at the University of Hull for their constructive comments and suggestions. Furthermore, Abdul Moin expresses his gratefulness to the Ministry of Research, Technology and Higher Education of the Republic of Indonesia for their financial support. 


\title{
Dividend Policy of Indonesian Listed Firms: The Role of Families and the State
}

\begin{abstract}
We investigate factors influencing the dividend policy of the listed Indonesian firms by focusing on agency costs and ownership structure. Our study finds that firms with higher conflicts of interest among managers and shareholders pay lower dividends. In the context of the conflicts of interest among major and minor shareholders, we find that such conflicts would exert little impact on dividend payments. Further, we find that the family-controlled firms prefer to pay less dividends whereas the corporations with higher state ownership are associated with larger dividend payments. Our findings are in line with the argument that the Indonesian state consider corporate dividends as one of the main sources of revenues other than corporate taxes in their government budget. This issue may have adverse effects on the growth of cash-constrained small and medium-sized enterprises.
\end{abstract}

Keywords: dividends, ownership structure, agency conflicts, Indonesia

JEL Classification: G35 


\section{Introduction}

For more than half a century, how managers make decisions on corporate dividend policies has been a mystery and there are some questions remains still unanswered regarding the economic rationale behind paying dividends (Rozeff, 1982; Baker et al., 2002). Scholars have relentlessly investigated dividend policy from different perspectives. These efforts are intended to seek out potential answers to a firm's motivations for paying dividends. With regard to the above statements, this study attempts to investigate the extent to which firms make decisions concerning dividend policy in the context of agency problems by focusing on an emerging market, Indonesia. As argued by La Porta et al. (2000b), such conflicts may occur between corporate insiders, such as managers and controlling shareholders, and outside investors such as minority shareholders.

Over the course of the last few decades, a large and growing body of literature has highlighted the agency theory from another perspective: the conflict of interest between the controlling and minority shareholders. Such conflicts have been reported to commonly occur in firms with concentrated ownership structure (see e.g., Claessens et al., 1999; La Porta et al., 2000a; Faccio et al., 2001). When the ownership structure is concentrated in the hands of a few dominant shareholders, these controlling shareholders can use their power to not only effectively control and monitor managers, but also expropriate minority shareholders if the protection afforded to the minority is too weak (Shleifer and Vishny, 1997). From this perspective, one can contend that when large shareholders gain almost complete control of the firm, they prefer to generate private benefits at the expense of the minority shareholders.

Some studies reveal that dividends can help protect the minority shareholders (Shleifer and Vishny, 1997; La Porta et al., 2000a). Mancinelli and Ozkan (2006) argue that the effectiveness of the role of dividends in reducing agency costs may depend on a company's ownership and control structure. Fairchild et al. (2014), based on Thai listed companies, reveal that increasing investor 
power via high ownership concentration is associated with higher dividend payments. Similarly, Renneboog and Szilagyi (2015) find that the controlling shareholders of Dutch firms actually demand higher dividends, suggesting that the presence of controlling shareholders and dividends complement each other in the reduction of agency problems. A recent international study by Tran et al. (2017) examines the relationships among dividend policy, shareholder rights and creditor rights. They find that expropriation issues have become more salient after the global financial crisis. Al-Malkawi et al. (2014) examine the dividend decisions of Omani firms and state that Oman is a unique case for investors and policy makers. Similarly, Indonesia has unique characteristics such as high ownership concentration, the influence of the state, politically connectedness of businesses and regulations regarding dividend policy. However, very few studies investigate how managers of the Indonesian Stock Exchange (IDX) firms make dividend decisions in this environment.

One of the novelties in this study is that we examine agency conflicts in terms of two perspectives: the conflicts of interest between managers and shareholders, and those between controlling shareholders and minority shareholders, which has been neglected by the extant literature. In doing so, we employ various proxies to quantify such conflicts. Our study highlights two main research questions: i) to what extent do agency conflicts influence dividend policy of Indonesian firms, and ii) does corporate ownership structure matter in setting dividend policy of Indonesian listed firms? These questions are important because their answers can raise issues related to the ownership structure (especially family and state ownership) and functioning of corporate governance practices of corporations in Indonesia, which is a very large emerging economy with unique characteristics. In other terms, inappropriate corporate ownership mix and inefficient corporate governance mechanisms may originate from strong relationship between politics and business, dominant family membership to control management and board of commissioners, and the role of government to appoint or replace directors of SOEs. Such sub-optimal practices would have adverse consequences on the corporate sector and the macroeconomic indicators in Indonesia. 
Therefore, by examining firms operating in a different environment, when compared to the firms in developed markets, this study can extend our understanding on how corporate payout policies are determined in different contexts.

The ownership structure of firms listed on the IDX as documented by Claessens and Fan (2002), is characterised by a high level of concentration, whereby two-thirds of firms are dominated by a single controlling shareholder. Equity stock is concentrated in hands of a few families and corporations and the State. In another study, Claessens et al. (1999) document that Indonesia has the greatest ownership concentration in East Asia, together with Thailand and Hong Kong, and that family shareholders are the main controllers of most of the firms listed in the IDX. Similarly, Husnan (2001) finds that top 15 families control 61.7 percent of market capitalization in Indonesian listed firms. Moreover, Sawicki (2009) documents that Indonesian listed firms had the highest ownership concentration and the lowest payout ratio during the post-crisis period of 1999-2003 as well as the second lowest ratio during the crisis period of 1997-1998. Similarly, La Porta et al. (1999) and Claessens and Fan (2002) have indeed identified that IDX firms have (i) high levels of ownership concentration, (ii) predominant family control, and (iii) low protective regulation for minority shareholders.

The ownership structure of firms on the IDX has not changed substantially and such shareholders are still dominant in these firms due to the absence of regulations that limit the stock ownership of particular shareholders. ${ }^{1}$ For instance, we find that in $17 \%$ of our sample firms the largest shareholder holds between $30 \%$ and $40 \%$ of the stocks of their firm in 2013. Furthermore, Faccio et al. (2001) document that the Asian value system is characterised by the dominance of

\footnotetext{
${ }^{1}$ In 2014, the Financial Service Authority, the security exchange commission governing Indonesian capital market, released new regulations obliging listed firms to increase shareholding for non-controller and non-primary shareholders to at least $7.5 \%$ of the paid capital. This means that the number of shares held by public shareholders is at least $7.5 \%$. The regulations also require that the minimum number of shareholders is 300 persons. However, the regulations do not explicitly limit the maximum percentage of shareholding by the controlling or primary shareholders. Only in the banking sectors is the limit to shareholdings explicitly regulated; that is, financial institutions, non-financial institutions, and individuals have the cap of maximum $40 \%, 30 \%$, and $20 \%$, respectively.
} 
family loyalties, which tends to foster crony capitalism. By examining the typical ownership formation of Indonesian firms, this study follows Faccio et al.'s (2001) study by suggesting that this issue should be approached in terms of a majority-minority problem as well as the principal-agent conflicts of interest.

The number of dividend policy studies focusing on the Indonesian context is limited. The existing Indonesian studies are based on surveys (see e.g., Ang et al., 1997; Kester et al., 1998; Baker and Powell, 2012). Denis and Osobov's (2008) study examining dividend policy in 33 developing countries included only one Indonesian firm in their sample. Atmaja (2016) examines the relationship between family-controlled firms and dividend policy in Indonesia, finding that family control has a significantly negative impact on dividend payouts. This correlation is also found in the study by Setiawan et al. (2016), who also confirm that state- and foreign-controlled firms have a positive effect on dividend policy. Ratnadi et al. (2013) examine corporate dividend policy in Indonesia by focusing on accounting conservatism. Our study investigates issues that have not been addressed by previous studies, particularly in using Indonesian data to examine the association between various ownership structure and dividend policy. These issues are concerned with whether the main owner, or the largest shareholder, plays a significant role in terms of influencing managers' dividend decisions, and whether firms dominated by different types of owners display different behaviours in determining dividend policy. Therefore, this paper distinguishes itself from the previous studies by focusing on: (i) the ownership structure data, which are categorized into family, state ownership, and foreign investors (ii) the presence of second largest shareholders, which has been neglected by previous studies in determining dividend policy; (iii) the role of corporate governance mechanisms on dividend policy; and (iv) the method of analysis by which we apply the probit method and the marginal effects to analyse the propensity of paying dividend as well as the Heckman two-step specification to consider sample selection bias with regards to the intensity of paying dividends. 
Indonesia is the fourth most populous country in the world and has the sixteenth largest Gross Domestic Product (GDP) with the economic growth rate of 5.6\% in 2013 (World Bank, 2014). Indonesia experienced a high growth of new stock listing after merging the Jakarta and the Surabaya stock exchanges into the IDX in 2007 (see Baker and Powell, 2012). By 2014, IDX had recorded a total market value of Indonesian Rupiah (IDR) 4,476,046 million ${ }^{2}$ (\$373 billion), with $\$ 499$ million in daily transactions, making Indonesia the second largest capital market in Southeast Asia. Moreover, the IDX management has set the ambitious target of overtaking Singapore's first position in the ranking by $2015 .{ }^{3}$ However, the IDX authority has not allowed foreign corporations to be listed in Indonesia. Consequently, this policy has the potential to hinder the acceleration of growth of the IDX in comparison to Singapore and Malaysia, which allows foreign corporations onto their stock exchanges. ${ }^{4}$ As for another economic policy making debate, the Indonesian government sets a specific amount of dividend that must be paid by state-owned enterprises (SOEs) for a given year, and that dividends become one of the key sources of revenues for the state. In addition, SOEs have roles as agents of profits and agents of development in the sense that they bring social mission to provide financial and managerial aids to help micro-, small-, and medium-sized enterprises to develop their businesses. The multitasking role contributed by SOEs may have impact on firms' strategic decisions such as corporate dividend policy. This suggests that SOEs face a trade-off between two roles: they must pursue target dividends to fulfil the government's demand and at the same time they are expected to provide social missions with appropriate economic activities. A similar reasoning is provided by the extant literature as they highlight the importance of efficient corporate sectors and well-functioning financial markets that would have direct implications on

\footnotetext{
${ }^{2}$ In January 2014, the average exchange rate was IDR10,223.16/USD (Source: Central Bank of Indonesia).

${ }^{3}$ See http://www.thejakartapost.com/news/2012/02/13/idx-unveils-ways-be-se-asia-s-largest-stock-market.html

${ }^{4}$ In addition, government regulation has imposed a stock exchange-related tax that is higher compared to those countries. For instance, Indonesia imposed a $15 \%$ tax on dividends, while capital gain is treated as ordinary taxable income. The sale of shares of publicly listed firms in IDX is subject to a tax of $0.1 \%$ of the transaction value, while no equivalent tax for capital gains has been imposed in Singapore and Malaysia. See also Geiler and Renneboog (2015), who study the relevance of tax regulations to payout policies in the U.K. Currently, the Indonesian government is considering reducing tax rates (even abolishing) on dividends in an attempt to transform their saving society into an investing society.
} 
economic growth (see e.g., Mallick and Yang, 2011; Levine and Zervos, 1998; Love and Zicchino, 2006).

Ang et al. (1997) identify the uniqueness of Indonesian firms in terms of organizational forms and business practices, while Leuz and Oberholzer-Gee (2006) contend that Indonesia has a unique financial environment, in which political connections have significant effects on the financing patterns of firms. In addition, Fu et al. (2015) argue that politically connected firms frequently obtain preferential treatment from banks regarding lending, particularly from state-owned banks. Moreover, their study also finds that informal political connections play a more important role in improving firms' access to finance than formal connections.

The distinctiveness of dividend policy among listed Indonesian firms can be considered from two points of view. Firstly, as identified by Goyal and Muckley (2013), Asian firms listed in countries such as Indonesia that adopt mainly civil law codes have poor investor protection and have the tendency to pay low dividends. ${ }^{5}$ Secondly, the dividend policy of Indonesian firms depends on the explicit discretions made by management as disclosed in their annual reports. For instance, firms set the minimum fund reserves on a yearly basis or set cash dividend payments at a given maximum percentage of net earnings. Such restrictions would have direct effects on the amount of dividends paid by the firms, which are related to the implementation of the firms' compliance of the Company Act passed in $2007 .{ }^{6}$ These policy changes may have implications for all shareholders. For majority shareholders who have control over company managers, these policies give potential benefits such as retaining the earnings, which may be used to repurchase stocks in order to enable them to increase

\footnotetext{
${ }^{5}$ Consistent with their findings, our study notes that the highest dividend per share paid by the Indonesian listed firms in 2013 was IDR817, which is equivalent to $\$ 0.08$, with an average of IDR28.3 or $\$ 0.003$. Moreover, due to the instability/depreciation of the exchange rate between the IDR and hard currencies, the real value of dividends will potentially lessen. This should raise an interesting question as to why international investors are interested in investing in IDX firms, as we find that foreign investors hold over $19 \%$ of shares in this country.

${ }^{6}$ Based on the article \#70 of the Act, if firms realize a positive balance of profit in a financial year, then it is compulsory for them to set aside a certain amount of their earnings as a reserve until it reaches $20 \%$ of the total subscribed and paidup capital. Furthermore, article \#71 of the Act points out that all net profits shall be distributed to shareholders as dividends after being deducted from the reserves, unless otherwise determined by the general meeting of shareholders.
} 
their control over a firm. Conversely, for minority shareholders, such a policy could be interpreted as the expropriation of their rights to obtain cash dividends.

The main findings of our study are as follows. The probit analyses report a highly negative association between agency costs and the likelihood of firms to pay dividends in the framework of conflicts between managers and shareholders, and highly positive association between the propensity to pay dividends with the state ownership. We further report a highly negative relationship between family ownership and dividends based on the robust OLS findings and the Heckman procedure addressing the sample selection bias. These results can possibly suggest that family shareholders may obtain private benefits by preferring lower dividends. Conversely, the effect of state ownership is positive toward paying more dividends and we obtained similar results as far as the position of the second largest shareholders is concerned. Finally, the factors related to board structure reveal that larger boards promote dividends, although independent board members fail in this aspect.

This paper proceeds as follows. Section 2 examines the existing literature and development of the hypotheses. Section 3 explains the models, methods and data used in this study. In Section 4, we report and explain the regression results, which are extensively discussed in Section 5. Finally, the last section concludes the paper.

\section{Literature Review and Hypothesis Development}

\subsection{The Hypotheses}

Agency theory is highly relevant in the study of issues of family governance (Carney, 2005). Claessens et al. (1999) hypothesize that family ownership leads to the expropriation of minority shareholders, and then find that family-dominated firms have a positive impact on cash flow rights but a negative impact on control rights. This evidence supports the view that minority shareholder expropriation occurs in firms dominated by a high level of family control. In the context of this 
unification of ownership and control, family-oriented firms should have low agency costs (Jensen and Meckling, 1979). However, Fama and Jensen (1983) identify several inefficiencies and valuereducing incentives in publicly traded family firms, such as underinvestment, inefficient risk bearing and minority shareholder expropriation.

La Porta et al. (2000a) point out that in the family-dominated firms of Indonesia, the top managers of such firms are influenced by the family, which has substantial control, indicating that the managers are at an arm's length from the shareholder (i.e., the family). Consequently, managerial behaviour can potentially represent shareholders' interests. As a consequence, less conflict occurs due to the convergence of interest between them. However, the managers can act, under family control, to maximize the family's wealth to the detriment of minority shareholders via tunnelling or assets expropriation using their business group (Bertrand et al., 2000).

Claessens and Fan (2002) argue that firms with more prevalent family control tend to be less protective of minority shareholders. Consequently, they are more vulnerable to assets expropriation committed by controlling shareholders. Consistent with the argument of Faccio et al. (2001), Asian values are characterised by the dominance of family loyalties, which tends to foster crony capitalism through the activity of an intra-group of business transactions serving to remove corporate resources. Under such family control, managers can use investments in the firm's cash flows for low returns or unprofitable projects, thus serving as another form of expropriation. Hence, such firms tend to pay less dividends. Therefore, we posit that:

H1. Firms with higher family ownership levels are associated with lower dividends payment or lower probability of paying dividends.

Mishra and Narender (1996) argue that, as the main owner, the state should rather obtain dividends due to the regulation of minimum dividend declaration unless there are proposals in hand for expansion or diversification. However, they report that SOEs in India pay a stagnant dividends 
per share in contrast to the increasing earnings per share. In a study based in China, where most of the publicly listed firms are state-owned, Wei et al. (2004) find that state ownership has a positive correlation with cash dividends. This finding is supported via another study in China by Bradford et al. (2007), who report that state ownership influences the cash dividends paid out; that is, the lower the state ownership, the lower the cash dividends. Recently, He and Kyaw (2018) show the importance of managerial and state ownership in China regarding investment inefficiency and dividends.

In Indonesia, many SOEs were established through the process of nationalizing what had previously been Dutch companies in the 1950s. However, the privatization programs of the 1990s and 2000s have driven some SOEs to list their shares on the stock market. This has brought consequences for their corporate governance, particularly in terms of a transition from a more feudalistic management to open and professional management. Once they become public firms, the investors require professional governance similar to that of private firms, including dividend decisions. In Indonesia, dividends from the SOEs are the main source of revenue for the governmental budget, besides tax receipts. Owing to the investor requirement for better governance, and government expectations for obtaining more revenues, SOEs are then expected to pay high dividends; therefore our study proposes the following hypothesis:

H2. Firms with higher state shares tend to pay more dividends or have higher tendency to pay dividends.

Agency costs are not directly unobservable (Baker and Weigand, 2015) but they emerge as a product of inefficiency of contractual relationship between corporate insiders and outside investors. Either managers or controlling shareholders with significant rights may use a firm's resources for their own benefits. In a firm, if an owner is also its manager, the agency conflicts tend to be minimal. However, within publicly listed firms owned by various shareholders, the contractual relationships 
bring about such conflicts whereby the managers (agents) may act for their own interests, which can be detrimental to shareholders' wealth.

La Porta et al. (2000b) argue that the conflict of interests occurs between corporate insiders and outside investors. The insiders can use firms' assets for their own benefit through various ways: excessive salaries, transfer pricing to other corporation under the same group of business, diverting assets or assets sales to themselves (see Shleifer and Vishny, 1997). In the context of managersshareholders conflict, owners should effectively monitor and control managers to align their interests. Additionally, managers having better information regarding their firms should act on shareholders' best interests. As agency costs arise due to the complexity of modern corporations, shareholders seek ways to alleviate such risks by reducing the likelihood of managers to expropriate firms' cash reserves. Further, a problem arises when conflicts of interest occur between controlling shareholders and minority shareholders. Effective corporate governance mechanisms with strong protection for minority shareholders may be one of the ways to reduce such conflicts. Easterbrook (1984) suggests that paying dividends provides a mechanism to reduce agency cost of free cash flow from inappropriate expending by managers or controlling shareholders. On the other hand, John and Knyazeva (2006) find evidence that firms with lower agency costs- as a result of well-governed firms- pay lower level of dividends.

Faccio et al. (2001) document that Indonesia is characterized as a country with high ownership concentration, low dividend payments, and poor corporate governance. These characteristics are potential to increase agency cost of free cash flows as firms' managers and controlling shareholders can expropriate cash for their own benefits. In addition, firms with high ownership concentration have potential violation of minority shareholders' interests as well as agency conflicts between managers and controlling shareholders (Fairchild et al., 2014). Agency theory posits that unless corporate profits are paid out to shareholders, corporate insiders may use 
the profits for their private benefits (see e.g., La Porta et al., 2000b). Similarly, Jensen (1986) argues that dividends can help mitigate agency problems as excessive free cash flows tend to be used by managers in inefficient ways.

Shareholders or potential investors perceive that firms with high agency conflicts are associated with high risks due to the inappropriate use of firms' cash holdings by managers. In addition, the presence of such substantial agency conflicts hints potentially poor corporate governance practices. To compensate for such risks, they require higher dividends payments. Thus, we hypothesize that there is positive association between agency costs and level of dividend payments.

H3. Firms with higher agency conflicts tend to pay higher dividends or have higher tendency to pay dividends.

\subsection{The Other Considerations}

\subsubsection{Degree of ownership concentration}

La Porta et al. (2000a) and Claessens et al. (1999) identify substantial differences in firm ownership between common law and civil law countries; and recently Jabbouri (2016) considers such country-specific differences when analysing the dividend policies of firms in Middle East and North Africa (MENA) region. Firms in common law countries, characterized by dispersed ownership and strong protection for minority shareholders, pay higher dividends than those in civil law countries. However, in the context of agency theory, the separation of ownership and control in dispersed ownership allows managers to pursue their own benefits due to less control from shareholders (La Porta et al., 2000a). In contrast, firms in civil law countries are associated with a high degree of concentration, weak property rights, an inefficient judicial system, and weak performance on the part of corporations (Claessens et al., 1999). Recent studies document the potential conflict of interest between controlling shareholders and minority shareholders in firms 
with a high degree of concentration (Claessens et al., 1999; La Porta et al., 2000a). Large shareholders with almost full control over the firm tend to obtain private benefits by accumulating more cash and paying lower dividends (Shleifer and Vishny, 1997; Mancinelli and Ozkan, 2006). Therefore, the higher the level of ownership concentration, the lower the dividends paid by the firm. Claessens and Fan (2002) argue that firms with high ownership concentration tend to be less protective of minority shareholders concerning assets expropriation. Means of expropriation on the part of the controlling shareholders include intergroup sales and services, transfer pricing, and the control of assets and other stakes (Shleifer and Vishny, 1997; Claessens et al., 1999). In addition, Gugler and Yurtoglu (2003) find that an increase in stakes controlled by the largest shareholders gives rise to a substantial increase in the level of concentration, which in turn tends to decrease dividend payouts.

\subsubsection{The role of second largest shareholders}

Multiple controlling shareholders may have an important role in determining dividend policy due to their power. Faccio et al. (2001) reveal different findings across countries regarding the existence of multiple shareholders in dividend policy. They claim that the presence of another large shareholder reduces agency conflict in European firms, but in East Asian firms the other large controlling shareholder tends to collude in expropriating the minority shareholders by paying lower dividends. On the other hand, Gugler and Yurtoglu (2003) find that the second largest shareholder is positively associated with dividends, meaning that their presence can alleviate agency conflict between majority and minority shareholders. In contrast, in examining Italian firms, Mancinelli and Ozkan (2006) highlight the importance of the second largest shareholder in corporate dividend policy.

\subsubsection{Foreign ownership}


Another common characteristic of emerging markets, such as Indonesia, is the presence of foreign shareholders. Their existence has significantly increased due to the impact of the liberalisation of the Indonesia Capital Market after the 1997-1998 crisis, whereby firms are now allowed to acquire up to $95 \%$ equity stake. When investigating Korean firms, Min and Bowman (2015) find that capital mobility from foreign investors is significantly influenced by the improvement of corporate governance system. This suggests that foreign investors seek target investment in low risk countries by expecting adequate return on their investment. Douma et al. (2006) argue that foreign investors have established substantial ownership in many industries in order to support their international operations. Chari et al. (2009) also argue that firms under the control of multinational corporations (MNCs) can realize gains and benefits through the attribution of the transfer of superior technology, a strong organizational capital and culture, and access to international capital markets. Foreign investors need more transparent information about how firms are managed. In addition, better supervision and control by MNCs enable a firm to promote better governance practices than those of domestic firms. In terms of dividends, foreign investors may require higher dividends to compensate for additional risk taking. Similarly, in a study conducted in Japan, Baba (2009) finds that foreign ownership has a positive and significant association with dividends.

Baba (2009) and Jeon et al. (2011) point out that foreign investors face a higher degree of informational asymmetry compared to domestic shareholders, which therefore leads firms to pay more dividends as opposed to retaining the earnings. On the other hand, Kim et al. (2007) find that U.S.-owned foreign subsidiaries pay a stable dividend repatriation to their U.S. parent, while the subsidiaries' dividend policy does not tend to follow their parent's dividend policy. Moreover, Jeon et al. (2011) affirm that the monitoring function of foreign institutional investors in emerging markets is more effective than domestic institutional investors because they apply global standards and practices. 


\subsubsection{Board size}

The role of the board is very significant as it performs the critical function of monitoring and advising top management (Coles et al., 2008). In addition, Boone et al. (2007) and Coles et al. (2008) explain that the size of the board is perceived to increase its effectiveness. However, other studies report that larger boards are less effective than smaller boards because of the lack of coordination and the problem of free-riding directors (Lipton and Lorsch, 1992). Coles et al. (2008) argue that large, complex and diversified firms should have larger boards to employ more experience, knowledge and better advice. However, Linck et al. (2008) find different evidence that firms with high $R \& D$ expenditure and high growth opportunities are associated with smaller boards, thus revealing that large firms do not always have larger boards. Linck et al. (2008) further find that firms structure their boards by considering the cost and benefits of the monitoring and advising performed by the board. As the main function of a board is to monitor and advise (Raheja, 2005), the larger the size, the more effective the management functions will be, while the managers, in turn, will be less likely to be prone to extract private benefits. Therefore, firms with larger boards will have better governance and pay higher dividends since larger boards bring more experience and knowledge to the table (Dalton et al., 1999), while complex, diversified and debt-financed firms have a greater need for advice and should have larger boards (Coles et al., 2008). We should expect that the larger the size of the board, the better the governance and therefore the higher dividend payments.

\subsubsection{Board independence}

The proportion of non-independent (inside directors) and independent (outside directors) members of a board is also an important factor to consider. Coles et al. (2008) argue that higher board independence allows for more effective monitoring of management, particularly for R\&D intensive firms. Such firms are likely to benefit from the representation of large insiders on the board to employ their specific expertise. However, Linck et al. (2008) find that firms with high R\&D 
expenditure and high growth are associated with less independent boards. They support the evidence that the more independent boards exist in a firm, the more opportunity they have to extract private benefits. Interestingly, this study also reveals that large firms do not always have more independent boards. The existence of an independent board in a board structure complements the insider members of the board insofar as the former provide more independent monitoring. However, the independent board members usually have less information about a firm's constraints and opportunities (Linck et al., 2008). On the other hand, Raheja (2005) argues that insiders have an important role in supplying an important source of information for the boards, however they may have distorted objectives due to the lack of independence from the CEO and private benefits. This argument is consistent with Hermalin and Weisbach's (1988) suggestion that firms with more complex operations should maintain more independent members on the board in order to provide expertise and advice to the CEO. The presence of more outsiders should be associated with higher dividends.

\subsubsection{Duality}

The identification of the position of chairman and CEO, whether or not they are held by the same person, is an important issue in measuring the strength of the governance mechanism. ${ }^{7}$ At the same time, the division of positions between different people is intended to maintain individual authority and power. As Arcot and Bruno (2006) argue, the separation of chairman and CEO is an important mechanism to ensure a balance and clarity of power and authority. The authors contend that there should be a clear division of the authority and responsibilities of the chairman and CEO, in order that each of them have unfettered powers. Therefore, to support good governance, firms with a separation between CEO and chairman often produce better governance. In addition, Linck et al. (2008) use the term 'combined leadership' to describe the CEO/chairman duality, suggesting

\footnotetext{
${ }^{7}$ See Karpavičius and Yu (2018) who examine the relationship between CEO stock incentives with dividend protection and the value and riskiness of corporations.
} 
that such a duality will increase his/her bargaining power and influence the firm's strategic decisionmaking. Therefore, maintaining a dual position for the $\mathrm{CEO}$ /chairman will be more likely to engender unfair decisions at the cost of the minority shareholders. In other words, firms with CEO and chairman duality are vulnerable to lower quality corporate governance practices (see e.g., Setiawan and Phua, 2013) because too much power is concentrated in one person, which might suggest lower dividend payments.

\subsubsection{Group affiliation}

A business group is a common organizational form in many countries. The group can take a pyramidal structure, a cross-holding form, or an even a more complex structure such as keiretsu (Japan) or chaebol (Korea). In Indonesia, a conglomeration of businesses is very common, whereby a group of companies covers several business activities and crosses industry sectors. However, the presence of a business group can make minority shareholders fear expropriation due to weak corporate law and lax enforcement mechanisms, this particularly applies in developing economies (Bertrand et al., 2000). Bertrand et al. (2000) find that the owners of business groups expropriate minority shareholders by tunnelling their firms' resources to other firms within the group of businesses. They argue that various forms of tunnelling, such as inter-firm loans with high or low interest rate, transfer pricing manipulation, and asset selling with an inappropriate price among their group of business are practices performed by owners of business groups who have substantial control over the firms. As the presence of group affiliation implies higher expropriation risk, this then is likely to lower dividend payments.

\subsubsection{Firm characteristics}

This study considers a number of company level control variables following the relevant literature. Larger firms tend to generate higher profits due to their economies of scale and scope, while they have a greater ease of access to sources of finance at a lower cost. Therefore, such firms 
are more likely to pay higher dividends, as evidenced by Fama and French (2001), Holder et al. (1998) and Grullon et al. (2002), among others. According to Smith and Watts (1992), size may be an important variable when detecting a conflict of interests between majority and minority shareholders; they nonetheless failed to detect a strong link between size and dividends. On the other hand, firms with high growth options might spend their earnings to finance growth. Grullon et al. (2002) and Fama and French (2001) point out that growth firms pay less dividends as external financing tends to be costly due to information asymmetry concerns between lenders and borrowers. Rozeff (1982), Lloyd et al. (1985) and Schooley and Barney (1994) have produced similar conclusions. Baba (2009) argues that firms with future growth opportunities signal good prospects to the shareholders. Bhattacharya's (1980) signalling hypothesis implies that firms with high future investment options tend to have their stocks undervalued by the market, which suggests that such firms pay less dividends to signal their expected good future profitability.

Rozeff (1982) argues that firms with high leverage pay lower dividends due to the transaction costs of external financing and payments to creditors. Mancinelli and Ozkan (2006) argue that firms bearing high debt face a high risk of financial distress, and as such they tend to accumulate cash to avoid cash shortfall. Similarly, Baba (2009) points out that firms with higher debt ratios tend to have lower free cash flows, and hence pay lower dividends. Leverage plays a vital role in reducing the conflict between majority and minority shareholders due to increasing external monitoring from creditors. If a firm has high debt, the cash flow available for dividends is low because of principal and interest payments, and it will, in turn, lower dividend payments. Furthermore, as profitability is one of the main sources of dividend payments, we would expect a positive association between profitability and dividends, as reported by Fama and French (2001), among others.

\section{Methods and Data}

\subsection{The source of data}


We employ data from Reuters Datastream as well as hand-picked data retrieved from the 2013 audited annual financial statement of the non-financial firms listed on the IDX (www.idx.co.id). As of December 2013, there were 464 listed firms, but after subtracting financial firms (74 firms), missing and incomplete data (16 firms) and delisted firms (5 firms), we finally obtained 369 sample firms to use in this analysis. Financial firms were excluded from the sample due to the fundamental differences in terms of regulation compared to non-financial firms. These exclusion criteria follow those of previous studies of Fama and French (2001) and Denis and Osobov (2008), among others.

\subsection{Dependent and explanatory variables}

This study uses four dependent variables: (i) Payer, a binary variable taking the value of 1 for dividend payers and 0 for non-payers; (ii) dividend per share (DPS); (iii) total dividends over total assets (DIVTA); and (iv) dividend payout ratio (DPR).

The explanatory variables are grouped into: (i) types and identity of share ownership and (ii) agency conflicts. High agency costs may stem from poor investment decisions such as the purchase of unproductive assets, which in return reduces revenues. Following Ang et al. (2000), we consider two proxies to quantify agency conflicts between managers and shareholders: (a) expenses ratio, which measures the effectiveness of the firm's management to control operating costs and other costs related to managerial excessive consumption, and (b) asset utilization ratio, which measures the effectiveness of the firm's management to deploy its assets. For the conflicts between small and large shareholders, we employ the constructs Degree of concentration, High concentration, Second largest and First second. The other groups for the explanatory factors are: iii) level of ownership concentration, (iv) corporate governance and board structure, and (v) other firm-specific factors as controlling variables. Table A1 in the Appendix provides the definitions of the variables.

\subsection{The empirical model}


This study adopts the probit, OLS, and Heckman's two-step estimation procedures. The probit method analyses the 'propensity' to pay; that is, the factors affecting the likelihood of IDX firms paying dividends, whereas the OLS regressions capture factors affecting the 'intensity' of payments. Heckman's (1979) approach is used to capture the two-step decision-making of dividend policy to address the sample selection bias due to the possibility that some potential determinants affect payout decisions. The Heckman procedure reduces the selection bias by incorporating into the analysis the factors that lead firms to pay or not to pay cash dividends before examining the magnitude of dividend payments. The use of this procedure is important and relevant in examining some of the potential determinants affecting both dividend decisions: the decision whether or not to pay (propensity to pay dividends) and how much to pay (level of dividend payments). The models are as follows:

Propensity to pay (Probit):

$\operatorname{Prob}\left(Y_{i}>0\right)=\beta_{0}+\beta_{1}$ Family $_{\mathrm{i}}+\beta_{2}$ State $_{\mathrm{i}}+\beta_{3}$ Agency conflict $_{\mathrm{i}}+\beta_{4}$ Concentration $_{\mathrm{i}}+\beta_{5}$ Second $_{\mathrm{i}}+$ $B_{6}$ Foreign $_{\mathrm{i}}+\beta_{7}$ Board size $_{\mathrm{i}}+\beta_{8}$ Board independence $_{\mathrm{i}}+\beta_{9}$ Duality $_{\mathrm{i}}+\beta_{10}$ Group affiliation $_{\mathrm{i}}+$

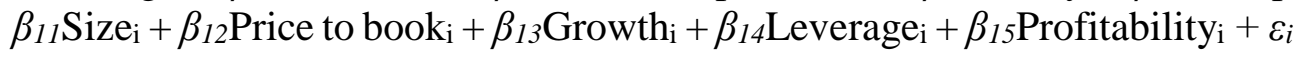

Intensity of payments $(O L S)$ :

$E(D P S, D I V T A, D P R \mid Y i>0)=\beta_{0}+\beta_{1}$ Family $_{\mathrm{i}}+\beta_{2}$ State $_{\mathrm{i}}+\beta_{3}$ Agency conflict $_{\mathrm{i}}+\beta_{4}$ Concentration $_{\mathrm{i}}+$ $\beta_{5}$ Second $_{\mathrm{i}}+\beta_{6}$ Foreign $_{\mathrm{i}}+\beta_{7}$ Board size $_{\mathrm{i}}+\beta_{8}$ Board independence $_{\mathrm{i}}+\beta_{9}$ Duality $_{\mathrm{i}}+\beta_{10}$ Group

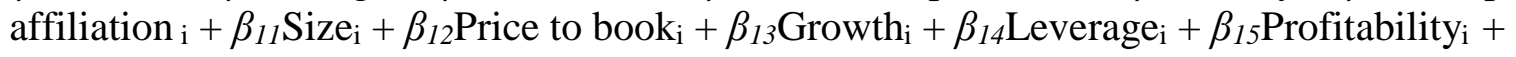
$\beta_{16} L_{a m b d a}+v_{i}$

where "Prob $\left(\mathrm{Y}_{\mathrm{i}}>0\right)$ " represents a firm's likelihood to pay dividends; "Y $\mathrm{Y}_{\mathrm{i}}$ " represents the level of dividend payments based on the variable DPS, DIVTA or DPR; "E(DPS, DIVTA, DPR $\mid Y i>0$ " represents the expected level of dividends conditioned upon if firms pay dividends; $\beta$ s are the estimable parameters; $\varepsilon_{i}$ and $v_{\mathrm{i}}$ are the error terms that are jointly normally distributed with zero 
means and with the correlation of $\rho$; "Lambda" is the inverse Mill's ratio obtained from Eq. (1) and inserted into Eq. (2) for the purpose of selection correction. ${ }^{8}$

Regarding the explanatory variables: "Family" represents the ownership held by family members based on the variable Family ownership 1, Family ownership 2, Family ownership 3 or Controlling family; "State" represents the ownership held by the State based on the variable State ownership 1, State ownership 2, or Controlling State; "Concentration" is the stock ownership concentration of a firm $i$ based on the variable Degree of concentration, or High concentration; "Second" represents the ownership level of the second largest shareholder based on the variable Second largest or First second; "Foreign" represents the ownership held by foreign shareholders based on the variable Foreign ownership 1, Foreign ownership 2, or Controlling foreign; "Board size" represents the size of the board; "Board independence" represents the proportion of outside board members; "Duality" indicates the presence of dual role of CEO and Chairman; "Group affiliation" shows if firms belong to any business group; "Size" measures the firm size; "Price to book" represents future growth options; "Growth" is a proxy for current growth rate; "Leverage" represents the capital structure mix and "Profitability" is return on assets. All of the variables are defined in the Appendix.

\section{Results and Findings}

\subsection{Descriptive statistics}

Table A2 provides correlation matrix of all variables used in this study. Correlation coefficients above 0.5 are marked with bold \&asterisk. The variance inflation factors (VIFs) confirm that we do not suffer from the multicollinearity problem as the figures are well below 10 .

\footnotetext{
${ }^{8} \mathrm{We}$ used the same explanatory variables in both the selection and output equations as one can assume that the factors impacting the propensity to pay dividends are also expected to influence the amount of dividend payments (see e.g. Fama and French, 2001 and Huang et al., 2011). Both models also include industry dummies. A significant Mill's ratio implies the presence of the sample selection bias.
} 
Table 1 exhibits the descriptive statistics. The table shows that the mean dividends per share (DPS) is IDR28.32 with a standard deviation of IDR80.75. The relatively high standard deviation and low mean indicate that the DPS of the IDX firms is highly dispersed across the firms. The dividends as a proportion of total assets records the mean of $1.6 \%$ with standard deviation of $5.9 \%$. Further, $47 \%$ of our sample firms paid cash dividends.

The level of concentration, on average, is about $61 \%$, indicating that most of the firms are to be placed in the category of concentrated ownership. The potential role of the second largest shareholders in decision-making seems significant as their proportion of holding shares is $18 \%$; the same argument can be put forward for the foreign shareholders, who own over $19 \%$ of the shares. Also, the divergence between the proportion of shares held by the first and second largest shareholders is $23 \%$, which suggests that the IDX firms may not have sufficient balance of power with regards to key block holders.

In Indonesia, families may use indirect ownership via cross-holdings. The direct ownership level for this type of shareholder is close to $4 \%$. We identified 19 state-owned enterprises (SOEs) in this study, and the State has one share in each of the firms with almost absolute voting rights. ${ }^{9}$ The level of state ownership is, on average, $3 \%$. Table 1 also shows that an average board consists of four directors. It also reveals that the proportion of outsiders on a typical board is close to $41 \%$.

\section{[PLEASE INSERT TABLE 1 HERE]}

Table 2 presents the distribution of equity ownership across different ranges, showing the level of investment made by the largest shareholders. The information in this table is intended to give a more comprehensive picture of the level of concentration of the listed Indonesian firms, particularly regarding the stock ownership by the largest shareholders. The first row indicates that there are 7 firms with the corresponding proportion of $1.9 \%$ in which the largest shareholder

\footnotetext{
${ }^{9}$ This share is called "red and white share" representing the colour on the Indonesian flag.
} 
possesses at least $90 \%$ of stocks. The last line informs us that there are 6 firms in which the largest shareholder possesses $9.99 \%$ of stocks or less, suggesting that only $1.63 \%$ of our sample companies can be categorized as highly dispersed firms. Table 2 indicates that when we use $10 \%$ as a cut-off point for ownership, over $96 \%$ of firms are controlled by a single largest shareholder. In addition, the most common range is between $30 \%$ and $39.99 \%$, constituting 63 firms or $17.07 \%$ of total firms.

\section{[PLEASE INSERT TABLE 2 HERE]}

Table 3 presents the distribution of sample firms based on the industry classification. The second and third columns display the number of firms which pay dividends and do not pay dividends, respectively. The $4^{\text {th }}$ column shows the number of firms in each industry either as dividend payers or non-payers. The trade and service group has the largest proportion with 98 firms (26.56\%), followed by basic industry sector with 58 firms $(15.72 \%)$. The smallest proportion is the agriculture group with only 15 firms $(4.07 \%)$.

Column 6 shows the proportion of firms which pay dividends for each industry. The agriculture industry has the largest proportion (66.67\%), followed by the consumer goods industry. The last column of Table 3 shows the average DPS in each industry and reveals that firms in the consumer goods (property and real estate) industry have the highest (lowest) DPS.

\section{[PLEASE INSERT TABLE 3 HERE]}

\subsection{Econometric Analyses}

\subsubsection{Probit regressions}

Table 4 analyses the determinants of paying cash dividends in the IDX firms. Panel A reports the marginal effects estimates within the framework of managers-shareholders conflict whereas Panel B shows the results for the major-minor shareholders conflicts of interest. 
The results in panels $\mathrm{A}$ and $\mathrm{B}$ Table 4 reveal that the family ownership-related variables have no significant effects on the propensity to pay dividends, which does not support our hypothesis 1. Yet, model 1 suggests some economic significance pertaining to family ownership: the corresponding marginal effect indicates that the likelihood of paying dividends increases by 25.5 percentage points as a response to the increase of one standard deviation (i.e., 11.9\%) of the family ownership, keeping the other variables at their mean values.

In Panel B, the effect of the state ownership on the probability of paying dividends is positive and the relationship is statistically significant for the proxy Controlling State. This finding is in line with our hypothesis 2 and suggests that the State has high interests on the dividend payments. The marginal effects in models 7 and 8 imply that when the largest shareholder is the State (as opposed to when it is not), the propensity to pay cash dividends goes up by about 30 percentage points.

Furthermore, Panel A shows that agency conflicts are highly and negatively associated with the tendency to pay dividends. This finding provides evidence that firms with high level of agency conflicts are less likely to pay dividends. ${ }^{10}$ Regarding the implications for the second type of agency conflicts, in Panel B, the marginal effect in model 5 suggests that a one-standard deviation increase in the degree of ownership concentration (i.e., 20.1\%) raises the propensity to pay dividends by 7.5 percentage points but the regression coefficient is statistically insignificant. Moreover, the marginal effect on Second largest in column 7 suggests that the likelihood of paying dividends increases by over 17.5 percentage points as a response to one standard deviation increase (i.e., $11.5 \%$ ) in the proportion of stocks held by the second largest shareholders. The effect for the other alternative factor, namely First second, as a proxy for the monitoring/moderating role of the second largest shareholder over the largest shareholder does not bear any statistical significance. Overall, it seems

\footnotetext{
${ }^{10} \mathrm{We}$ use the reciprocal of asset turnover ratio as a proxy for this type of agency conflicts and report the results accordingly. We also use expense ratio as an alternative proxy: this ratio measures the effectiveness of the firm's management to control operating costs and other costs related to managerial excessive consumption. The untabulated regressions (available upon request) show that both constructs yield results that are qualitatively the same.
} 
the conflicts among small and large shareholders in Indonesia do not significantly influence the decision whether to pay dividends.

The effects of foreign ownership-related variables on the propensity of paying dividends are insignificant in both panels. Further, among the board structure variables, only Board size is statistically significant; its positive coefficient indicates that the probability of paying dividends is heightened by a larger number of board members. Finally, in Panel A, all the firm-specific characteristics are significant: Size, Price to book and Profitability (Growth) are positively (negatively) correlated to the propensity to pay dividends; in Panel B, Leverage is the only insignificant firm-specific factor.

\section{[PLEASE INSERT TABLE 4 HERE]}

\subsubsection{The OLS analysis for the level of dividend payments}

Table 5 exhibits the OLS results, focusing on the potential conflicts between managers and shareholders. Panel B provides evidence that all family ownership-related variables show highly negative association with the level of dividends relative to assets. This set of results supports our expectation as predicted in hypothesis 1 .

The effect of the state ownership on the level of dividends is positive in all panels, and the relationship is generally statistically significant. These findings support our hypothesis 2 , and imply that the State as a major shareholder has some high interests on corporate payouts and considers cash dividends as important source of revenue for the governmental budget.

The important finding revealed in Table 5 is that firms with higher level of agency costs have lower level of dividend payments. This result is not in line with our hypothesis 3 and indicates that firms with higher agency conflicts prefer to retain cash. Possibly, such firms would want to avoid costly external borrowing and hence intend to increase their internal reserves for future use.

[PLEASE INSERT TABLE 5 HERE] 
Table 6 provides the OLS results, focusing on the perspective of minor-major shareholders conflicts of interest. Panel B reveals that, as predicted in our hypothesis 1, family ownership is associated with lower dividends relative to assets. In addition, we report consistent results in all panels showing that the level or presence of state ownership is positively correlated to the amount of dividend payments in IDX firms, which confirms our hypothesis 2 .

The variable Second largest has a positive and significant coefficient estimate in Panel A, which suggests that the level of shareholdings by the second largest shareholders may influence Indonesian managers' decisions to pay more dividends. It is possible that this is an attempt to mitigate the potential expropriation risks.

Regarding the board structure variables, firms with a larger board size have significantly higher dividends per share and dividend payout ratios. Also, almost all of the firm-specific factors except leverage are significantly related to dividend payments: firms with higher price-to-book ratio and profitability or firms with lower growth pay more dividends. DPS is the only dependent variable with a significant association with firm size. Another finding is that although higher future growth options means paying more dividends, the opposite holds for the current growth levels.

\section{[PLEASE INSERT TABLE 6 HERE]}

\subsubsection{Heckman procedure}

This section is intended to check the robustness of the previous analyses regarding the consistency of the results by considering the potential sample selection bias that is inherent in studies of dividend policy decisions. Table 7 focuses on the conflicts between managers and shareholders and table 8 reflects on the minor and major shareholders' conflicts. In panels B and C in Table 7, based on the significant $p$-values pertaining to the Mill's lambda, there is some evidence which suggests the presence of the issue of selection bias. It should also be noted that the Heckman 
regression coefficients would still be consistent and efficient even if the sample selection bias is statistically not very salient (see e.g., Farrell et al., 2014).

In Table 7, we observe that, except in one case, family and state ownership do not exert any significant influence on the amount of dividends once we figure out the determining factors why firms do (not) pay dividends. On the other hand, Table 7 shows that, again, the conflicts between managers and shareholders lead to more conservative dividend policy.

In Panel B Table 8, the family ownership-related variables exert highly significant and negative impacts on the level of dividend payments, suggesting that family ownership is associated with lower dividends. Consistent with the previous results in Table 6, these findings provide evidence again for our hypothesis 1 . Regarding the state ownership, we again report similar results as the coefficients are generally positive and significant, which supports our hypothesis 2 . On the other hand, as in the previous analyses, our variables related to conflicts among small and large shareholders do not appear to have significant effects on the level of dividend payments.

In tables 7 and 8, board size has consistently strong and positive correlations with dividends. This may suggest that board size can have a significant role in promoting better corporate governance by alleviating the conflict of interests between majority and minority shareholders. In contrast, the negative correlation between board independence and dividend payments (see table 7) may indicate the poor implementation of corporate governance principles in the IDX firms owing to the ineffective role of outsider members. Tables 7 and 8 show that all other firm-specific variables obtain similar coefficient estimates under the Heckman procedure and are comparable to the OLS results.

[PLEASE INSERT TABLE 7 AND TABLE 8 HERE] 


\section{Discussion}

This study gives evidence that the structure of Indonesian listed firms is characterised by concentrated ownership, whereby $91 \%$ of firms are under a single and largest shareholder who holds at least $20 \%$ of company shares. This finding is consistent with La Porta et al. (1999) who find that most Asian firms fall under this concentrated ownership. In an effort to reduce ownership concentration of IDX firms, the Indonesian government has given an incentive of tax reduction for firms whose shares are held by public at a minimum of 40\% (Wardhana et al., 2014). Wardhana et al. (2014) report that controlling shareholders of Indonesian firms, generally non-financial firms with a close relationship with the founder family, have dominant roles in determining dividend policy and even surpassing the authority of corporate managers. They further document that such shareholders have the power to decide not only on dividend policy but also on the firms' other strategic decisions such as capital structure, target profit or issuing new equity, which has some implications for macroeconomic indicators. This fact contrasts with the situation in the U.K. and the U.S., in which the concentration of ownership by a single shareholder is uncommon (Shleifer and Vishny, 1997). In addition, in the U.S., the market has the power to force management to distribute cash dividends to investors (Bradford et al., 2007).

Large shareholders tend to consume private benefits by accumulating more cash and paying lower dividends, and when ownership is in the hands of dominant shareholders, they can effectively control and monitor managers (Shleifer and Vishny, 1997; Jeon et al., 2011). Such effective controls could provide the benefits of alleviating the divergence of interests and reducing the agency problem which arises between the principal and agent (Shleifer and Vishny, 1986; Short et al., 2002). However, in the context of Indonesia, another situation is that the composition of the boards of directors is family-related, which can be identified by looking at the surnames of board members. This study is consistent with the evidence found by La Porta et al. (1999) confirming that in such firms the family often supplies the CEO. Therefore, this study suggests that higher concentrated 
ownership can be an indication of effective monitoring and control of shareholders towards managers.

An important finding of this study is that family-related variables have a negative and significant relationship with dividends, suggesting that family-controlled firms pay less dividends. This evidence supports Faccio et al. (2001), who argue that such firms are vulnerable to the expropriation of minority shareholders by distributing low dividends. Another possible explanation is that such firms preserve earnings to support internal financing because, by avoiding the use of external financing to finance new investments, family-oriented shareholders would aim to protect their ownership and control within the firm. Our study suggests that the implementation of projects may be hindered by high agency conflicts and sub-optimal behaviour of family-controlled firms. Clearly, this aspect suggests that the intricacies and conflicts within the listed Indonesian firms will influence corporate financial and real investment decisions that would have direct links with the economic growth. Our discussion is parallel to the issues raised by Mallick and Yang (2011) who emphasise that the conflicts of interests impact firms' financial and innovation decisions. In addition, although family-controlled firms have low agency costs (Jensen and Meckling, 1979), a manager of an Indonesian firm may act to maximize the family's wealth at the risk of minority shareholders via assets' expropriation.

The positive and significant correlation between state ownership and dividends indicates that the state tends to require high dividends. This evidence is supported by other empirical studies in emerging markets such as in India by Mishra and Narender (1996), and in China by Wei et al. (2004) and Bradford et al. (2007). In Indonesia, public SOEs run strategic businesses including those in the pharmaceutical industry, infrastructure, mining and telecommunications. Some SOEs also obtain benefits from a monopolistic position in various sectors such as gas (PT Perusahaan Gas Negara), telecommunications (PT Telkom) and mining exploration (PT Tambang Timah). Historically, the involvement of government on business activities can be traced back into the nationalization of 
Dutch companies occurred in 1950s. Moreover, these findings signal that dividends are important for government, and listed SOEs serve as cash-cows for the government to foster non-tax revenues. ${ }^{11}$

We find that the link between foreign ownership and dividends is insignificant. This is inconsistent with Baba (2009) and Jeon et al. (2011) who argue that foreign investors require high dividends to compensate for a higher degree of informational asymmetry. High dividends can be understood as compensation for both the increase in risk and the cost of monitoring. Nevertheless, with regards to the monitoring costs due to the distance of the location between foreign investors and the firm, this may not be a significant obstacle. This can be explained by the fact that most of the foreign institutional investors are Singapore-headquartered corporations or multinationals having a branch office in Singapore. With respect to our main findings, the negative association between the intensity of agency conflicts and dividends- owing to underdeveloped capital and money markets in Indonesia- may drive the insignificant relationship between dividends and foreign ownership.

This study finds evidence that the presence of second largest shareholders can have effects on corporate dividend policy. However, this finding conflicts with the study by Mancinelli and Ozkan (2006). A possible explanation is that the largest and the second largest shareholders have the chain into the same ultimate control of shareholders, which is particularly the case in the familycontrolled firms. Another explanation is that, in many firms, the second largest shareholder with more than $10 \%$ stake or a substantial amount of shares is regarded as a controlling shareholder. The Indonesian Stock Exchange requires that only a shareholding with a minimum $10 \%$ equity has voting rights in a firm's annual general meeting. However, the regulation is not binding, entailing that a firm may apply their own particular regulation to set minimum equity and thus obtain control

\footnotetext{
${ }^{11}$ For the years 2013 and 2014, SOEs contribute to the government revenues as much as IDR34 trillion and IDR40 trillion, respectively.
} 
rights. These firms may issue a different class of stocks or set a specific agreement with particular shareholders regarding rights of control.

A director's individual power can influence the propensity and intensity of paying dividends. Such an effect may suggest that firms with a larger board size pay higher dividends, as this study reports. We can interpret this finding to imply that a firm with a larger board is potentially better governed than one with a smaller board, which is why the former will pay larger dividends. This result is consistent with Raheja (2005) and Coles et al. (2008) who argue that larger board size allows managers to function more effectively. This means that managers are less likely to extract private benefits.

The governance mechanisms used by Indonesian firms have a unique structure -given the implementation of Company Act 2007. The board of commissioners has the authority to monitor the board of directors as firm executives. The appointment of an independent commissioner is mandatory, according to the regulations of the Indonesia Security Exchange Commission. This appointment is intended to promote corporate governance principles and mechanisms to protect minority shareholders' interest from improper treatment by controlling shareholders or by managers. However, this study finds a negative correlation between board independence and dividends (see the Heckman results), suggesting that firms with more independent commissioners tend to pay less dividends. Furthermore, this denotes that the presence of independent commissioners is not an effective device for monitoring the board of directors or promoting mechanisms of good governance because of their weak position compared to non-independent commissioners. Ideally, the independent commissioners would be acting as 'the balance of power' in relation to the nonindependent commissioners, who are commonly regarded as the main owners of the firm. This observation is related to the implications of the one of our main findings that have surprisingly showed that higher agency costs reduce dividend payments. 
This finding contradicts the argument by Coles et al. (2008) that a number of independent board members allows for more effective monitoring of management. This raises the issue that insiders (the board of directors together with the majority shareholder) may expropriate minority shareholders regarding dividend payments by overriding the role of the independent commissioners. On the other hand, the negative correlation between the number of independent commissioners and dividends supports the substitution theory as discussed in La Porta et al. (2000b). According to this theory, poorly governed firms use dividends to gain the trust of the public regarding a firm's interest in raising future equity from capital markets.

Linck et al. (2008) argue that the duality (CEO/chairman) position increases bargaining power but tends to worsen corporate governance quality. Our study, however, failed to find a statistically significant link between duality and dividends. By examining the structure of boards in Indonesian listed firms, this study reveals that there are firms in which (a) the CEO is also the son of the president of the commissioner, (b) the president of the commissioner is the son of the firm's founder, who is still alive, (c) the CEO and some directors are members of the family of main stock holders, and (d) the CEO is in the family of a member of the board of the commissioner.

As predicted, company size is positively and significantly correlated with dividends, indicating that the larger the firm, the higher the dividend payments. This is consistent with the reasoning that the greater the stability and cash reserves of large firms, the greater the potential of the firm to pay more dividends (Lintner, 1956; Rozeff, 1982; Fama and French, 2001; Sawicki, 2009). Grullon et al. (2002) also find that firms with larger assets pay much higher dividends than those with smaller assets. Smith and Watts (1992) argue that examining the relationship between assets and dividends provides a weak means of detecting a conflict of interest between majority and minority shareholders.

According to Bhattacharya's (1980) signalling hypothesis, firms with higher future investments should pay less dividends. However, the IDX firms in our study showed an opposite 
pattern, which may be related to the different characteristics of Indonesian capital markets. ${ }^{12}$ It should be noted that high growth firms in Indonesia do not necessarily have to have their stocks undervalued, which would, according to the signalling hypothesis, lead them to pay less dividends. On the other hand, we find that a firm's current growth rate has a negative correlation with dividends. This is consistent with the findings of most of the previous studies (e.g., Grullon et al., 2002; Fama and French, 2001; Rozeff, 1982; Lloyd et al., 1985; and Schooley and Barney, 1994). This finding supports the argument that high growth firms prefer to retain their income as internal financing by not paying dividends, which is in line with the pecking order hypothesis proposed by Myers and Majluf (1984).

Firm profitability shows a strong and positive correlation with dividend policy. This supports the evidence that firms with a high level of profitability will obtain more cash to pay high dividends (Fama and French, 2001; Mitton, 2004; Jeon et al., 2011). In the Indonesian context, dividend policies across firms are not uniform. One firm sets dividend payments at a maximum of $30 \%$ of net earnings. Other firms do not pay dividends because they must set a minimum amount for the statutory reserves and will pay dividends as long as the appropriation for statutory reserves is fulfilled. Consequently, the amount of dividends paid is determined by the residual net profit after being subtracted from the mandatory reserves set by the firms. Additionally, although firms are able to generate profit, they are not likely to pay dividends if the profit is only available for the minimum mandatory reserves.

The structure of business groups (conglomeration) in the Indonesian business environment has become a common feature, much as in other Asian countries (Sato, 2004). However, they are not as complex as Japanese keiretsu with their interlocking structure. The growth of conglomerations cannot be separated from the firms' strategy to exploit a wide variety of industries

\footnotetext{
${ }^{12}$ Khurana et al. (2006) note that market imperfections and the low quality of institutions related to investors' protection make external financing expensive and difficult to access, which is related to the case of Indonesia. They find that financial development of countries reduces the reliance of firms on internal financing.
} 
to support their business operations and interests within the group. In addition, the conglomeration phenomenon that was pioneered by Indonesian-Chinese businessmen, who gained privileges by the New Order policy in the early 1970s, has been the machine of economic growth (Lasserre, 1993). Nevertheless, our study failed to find a significant relationship between dividends and business group affiliation. This finding contrasts with the study by De Jong et al. (2009), who raise the debtservice hypothesis in explaining that the dividend decisions of firms within the group are affected by the parent of the firms, and that the parent influences the subsidiary's dividend policy as an effort to seek external financing to pay the parent's debt.

\section{Conclusion}

This study investigates how managers undertake payout decisions by focusing on corporate ownership structure and corporate governance mechanisms in Indonesia, which has a unique business, legal and social environment. This study finds some salient evidence which can enrich the dividend policy literature particularly in developing markets. Renneboog and Szilagyi (2015) emphasized how they had reopened the debate as to whether the level of dividend payments is associated with different corporate governance regimes. Therefore, our paper is timely at least in the sense that their key findings contrast with ours. Our univariate analysis revealed that the listed Indonesian firms have a high level of concentration: as many as 96\% (91\%) of firms are concentrated with the single largest shareholder at least 10\% (20\%) of shares.

Our first set of main findings reveals that the effects of state ownership on dividends are positive and significant, suggesting that the presence of the state as an influential shareholder can possibly help mitigate concerns related to expropriation risk in Indonesia. Our second set of main findings suggests that family ownership and dividend payments are negatively correlated. This evidence implies that the minority shareholders may be vulnerable to expropriation risk by family or large controlling shareholders, noting that this negative link can be attributed to pecking order theory of capital structure that family-owned firms might be following. Our third set of main results 
shows that agency conflicts between managers and shareholders negatively affect the level of dividend payments, implying that firms tend to retain their earnings rather than returning to their shareholders. In other words, one can contend that firms with higher agency conflicts prefer to accumulate internal cash reserves rather than to seek funds from external borrowing. On the other hand, the sizeable marginal effects based on the probit analysis indicate that the second largest shareholders have effective roles in compelling managers to distribute cash dividends. It can thus be contended that the second largest shareholders and the family shareholders may have a conflict of interests.

This study also finds that there is a strong correlation between the size of the board and dividends, which justifies the importance of the board's role in promoting better corporate governance practices supported by the effectiveness of control by dominant shareholders. Interestingly, the presence or the proportion of independent commissioners in the board of IDX firms has negative effects on dividends, which indicates that these board members are not effective enough to influence corporate dividend policies, probably due to the strong dominance of nonindependent commissioners who can be influenced the main shareholders.

An appropriate ownership structure of listed Indonesian firms should be able to alleviate agency problems due to the increasing monitoring and control of incumbent managers by owners. In contrast, the dominance of a single large shareholder with the absence of a 'balancing power' from other shareholders may have negative impact on corporate governance mechanisms with undesirable outcomes such as the increasing vulnerability of minority shareholders to the risk of expropriation.

Future research could use panel data to increase the number of firm-years as well as examine the ultimate ownership within the complex structures of IDX firms - such as pyramidal, crossholdings and other interlocking ownership. 


\section{References}

Al-Malkawi, H.A.N., Bhatti, M.I., Magableh, S.I., 2014. On the dividend smoothing, signaling and the global financial crisis. Economic Modelling, 42, 159-165.

Ang, J.S., Fatemi, A., Tourani-Rad, A., 1997. Capital structure and dividend policies of Indonesian firms. Pacific-Basin Finance Journal, 5 (1), 87-103.

Ang, J.S., Cole, R.A., Lin, J.W., (2000). Agency costs and ownership structure. Journal of Finance 55 (1), 81-106.

Arcot, S., Bruno, V., 2007. One size does not fit all, after all: evidence from corporate governance. http://dx.doi.org/10.2139/ssrn.887947.

Atmaja, L.S., 2016. The impact of family control on dividend policy: Evidence from Indonesia. International Research Journal of Business Studies, 9 (03), 147-156.

Ashraf, B.N., Bibi, B., Zheng, C., 2016. How to regulate bank dividends? Is capital regulation an answer? Economic Modelling, 57, 281-293.

Baba, N., 2009. Increased presence of foreign investors and dividend policy of Japanese firms. Pacific-Basin Finance Journal, 17 (2), 163-174.

Bhattacharya, S., 1980. Nondissipative signaling structures and dividend policy. Quarterly Journal of Economics, 1-24.

Baker, K.H., Powell, G.E., 2012. Dividend policy in Indonesia: survey evidence from executives. Journal of Asia Business Studies, 6 (1), 79-92.

Baker, H. K., Powell, G. E. \& Veit, E. T. (2002) Revisiting managerial perspectives on dividend policy. Journal of Economics and Finance, 26(3), 267-283.

Baker, H.K., Weigand, R. (2015) Corporate dividend policy revisited. Managerial Finance, 41(2), 126-144.

Bertrand, M., Mehta, P., Mullainathan, S., 2000. Ferreting out tunneling: An application to Indian business groups. National Bureau of Economic Research.

Boone, A. L., Casares Field, L., Karpoff, J. M., Raheja, C. G., 2007. The determinants of corporate board size and composition: An empirical analysis. Journal of Financial Economics, 85 (1), 66-101.

Bradford, W., Chen, C., Zhu, S., 2007. Ownership structure, control chains, and cash dividend policy: evidence from China. Center for China Finance and Business Research Working Paper Series, Vol. 20. 
Carney, M., 2005. Corporate governance and competitive advantage in family-controlled firms. Entrepreneurship Theory and Practice, 29 (3), 249-265.

Chari, A., Chen, W., Dominguez, K. M., 2009. Foreign ownership and firm performance: emerging-market acquisitions in the United States. National Bureau of Economic Research.

Claessens, S., Djankov, S., Fan, J. P., Lang, L. H., 1999. Expropriation of minority shareholders: evidence from East Asia. Policy Research Working Paper Series. The World Bank.

Claessens, S., Fan, J. P., 2002. Corporate governance in Asia: a survey. International Review of Finance, 3 (2), 71-103.

Coles, J. L., Daniel, N. D., Naveen, L., 2008. Boards: does one size fit all? Journal of Financial Economics, 87 (2), 329-356.

Dalton, D. R., Daily, C. M., Johnson, J. L., Ellstrand, A. E., 1999. Number of directors and financial performance: a meta-analysis. Academy of Management Journal, 42 (6), 674-686.

DeJong, D.V., De Jong, A., Mertens, G., Hege, U., 2009. Leverage in pyramids: When debt leads to higher dividends. ECGI-Finance Working Paper, (261).

Denis, D. J., Osobov, I., 2008. Why do firms pay dividends? International evidence on the determinants of dividend policy. Journal of Financial Economics, 89 (1), 62-82.

Douma, S., George, R., Kabir, R., 2006. Foreign and domestic ownership, business groups and firm performance: evidence from a large emerging market. Strategic Management Journal, 27 (7), 637-657.

Easterbrook, F., (1984). Two agency-cost explanations of dividends, American Economic Review 74, 650-659.

Faccio, M., Lang, L. H., Young, L., 2001. Dividends and expropriation. American Economic Review, 91 (1), 54-78.

Fama, E. F., French, K. R., 2001. Disappearing dividends: changing firm characteristics or lower propensity to pay? Journal of Financial Economics, 60 (1), 3-43.

Fama, E. F., Jensen, M. C., 1983. Separation of ownership and control. Journal of Law and Economics, 26 (2), 301-325.

Fairchild, R., Guney Y., Thanatawee, Y, 2014. Corporate dividend policy in Thailand: theory and evidence. International Review of Financial Analysis, 31 (1), 129-151.

Farrell, K., Unlu, E., Yu, J., 2014. Stock repurchases as an earnings management mechanism: The impact of financing constraints. Journal of Corporate Finance, 25, 1-15.

Fu, J., Shimamoto, D., Todo, Y., 2015. Can firms with political connections borrow more than those without? Evidence from firm-level data for Indonesia. WINPEC Working Paper Series No.E1513. 
Geiler, P., Renneboog, L., 2015. Taxes, earnings payout, and payout channel choice. Journal of International Financial Markets, Institutions and Money, 37, 178-203.

Goyal, A., Muckley C., 2013. Cash dividends and investor protection in Asia. International Review of Financial Analysis, 29, 31-43.

Grullon, G., Michaely, R., Swaminathan, B., 2002. Are dividend changes a sign of firm maturity? Journal of Business, 75 (3), 387-424.

Gugler, K., Yurtoglu, B. B., 2003. Corporate governance and dividend pay-out policy in Germany. European Economic Review, 47 (4), 731-758.

Heckman, J.J., 1979. Sample selection bias as a specification error. Econometrica, 153-161.

He, W., Kyaw, N.A., 2018. Ownership structure and investment decisions of Chinese SOEs, Research in International Business and Finance, 43, 48-57.

Hermalin, B. E., Weisbach, M. S., 1988. The determinants of board composition. RAND Journal of Economics, 19 (4), 589-606.

Holder, M.E., Langrehr, F.W., Hexter, J.L., 1998. Dividend policy determinants: An investigation of the influences of stakeholder theory. Financial Management, 73-82.

Huang, J.J., Shen, Y., Sun, Q., 2011. Nonnegotiable shares, controlling shareholders, and dividend payments in China. Journal of Corporate Finance, 17, 122-133.

Husnan, S., 2001. Indonesia, in: Zhuang, J., Edwards, D., \& Capulong, M.V.A. (Eds.), Corporate Governance \& Finance in Asia: A study of Indonesia, Republic of Korea, Malysia, Philippines, \& Thailand. Asian Development Bank, Manila, pp. 1-51.

Jabbouri, I., 2016. Determinants of corporate dividend policy in emerging markets: Evidence from MENA stock markets. Research in International Business and Finance, 37, 283-298.

Jensen, M. C., Meckling, W. H., 1979. Theory of the firm: Managerial behavior, agency costs and ownership structure. Springer.

Jeon, J. Q., Lee, C., Moffett, C. M., 2011. Effects of foreign ownership on payout policy: Evidence from the Korean market. Journal of Financial Markets, 14 (2), 344-375.

John, K. and Knyazeva, A. (2006). Payout policy, agency conflicts, and corporate governance. Available at SSRN: http://dx.doi.org/10.2139/ssrn.841064

Karpavičius, S., Yu, F. (2018). The impact of dividend-protected CEO equity incentives on firm value and risk. Economic Modelling, 71, 16-24.

Kester, G.W., Chang, R.P., Echanis, E.S., Mansor, M.I., Skully, M.T., Soedigno, S., Tsui, K., 1998. Executive views on dividends and capital structure policy in the Asia Pacific region, in Choi, J.J., Doukas, J.A. (Eds.), Emerging Capital Markets: Financial and Investment Issues. Quorum Books, Westport, CT, pp. 113-135. 
Khurana, I.K., Martin, X., Pereira, R., 2006. Financial development and the cash flow sensitivity of cash. Journal of Financial and Quantitative Analysis, 41(4), 787-808.

Kim, Y. H., Rhim, J. C., Friesner, D. L., 2007. Interrelationships among capital structure, dividends, and ownership: evidence from South Korea. Multinational Business Review, 15 (3) , 25-42.

La Porta, R., Lopez-de-Silanes, F., Shleifer, A., 1999. Ownership structures around the world. Journal of Finance, 54 (2), 471-517.

La Porta, R., Lopez-de-Silanes, F., Shleifer, A., Vishny, R.W., 2000a. Investor protection and corporate governance. Journal of Financial Economics, 58 (1), 3-27.

La Porta, R., Lopez-de-Silanes, F., Shleifer, A., Vishny, R. W., 2000b. Agency problems and dividend policies around the world. Journal of Finance, 55, 1-33.

Lasserre, P., 1993. The coming age of the Indonesia-Chinese conglomerate. INSEAD, Euro-Asia Research Center.

Leuz, C., Oberholzer-Gee, F., 2006. Political relationships, global financing, and corporate transparency: Evidence from Indonesia. Journal of Financial Economics, 81 (2), 411-439.

Levine, R. and S. Zervos. 1998. Stock markets, banks, and economic growth. American Economic Review, 88(3), 537-558.

Linck, J. S., Netter, J. M., Yang, T., 2008. The determinants of board structure. Journal of Financial Economics, 87 (2), 308-328.

Lintner, J. (1956). Distribution of Incomes of Corporations among Dividends, Retained Earnings, and Taxes. The American Economic Review, 46, (2), 97-113.

Lipton, M., Lorsch, J. W., 1992. A modest proposal for improved corporate governance. The Business Lawyer, 48 (1), 59-77.

Lloyd, W. P., Jahera, J. S., Page, D. E., 1985. Agency costs and dividend payout ratios. Quarterly Journal of Business and Economics, 24 (3), 19-29.

Love, I. and L. Zicchino. 2006. Financial development and dynamic investment behavior: evidence from panel VAR. Quarterly Review of Economics and Finance, 46(2), 190-210.

Mallick, S. and Yang, Y., 2011. Sources of financing, profitability and productivity: first evidence from matched firms. Financial Markets, Institutions \& Instruments, 20(5), 221-252.

Mancinelli, L., Ozkan, A., 2006. Ownership structure and dividend policy: evidence from Italian firms. European Journal of Finance, 12 (03), 265-282.

Min, B. S., Bowman, R.G., 2015. Corporate governance, regulation and foreign equity ownership: lessons from Korea. Economic Modelling, 47, 145-155.

Mishra, C. S., Narender, V., 1996. Dividend policy of SOEs in India: an analysis. Finance India, $10(3), 633-645$. 
Mitton, T., 2004. Corporate governance and dividend policy in emerging markets. Emerging Markets Review, 5 (4), 409-426.

Myers, S. C., Majluf, N. S., 1984. Corporate financing and investment decisions when firms have information that investors do not have. Journal of Financial Economics, 13(2), 187-221.

Raheja, C. G., 2005. Determinants of board size and composition: a theory of corporate boards. Journal of Financial and Quantitative Analysis, 40 (2), 283-306.

Ratnadi, N.M.D., Sutrisino,T., Achsin, M., Mulawarman, A. D., 2013. The effect of shareholders' conflict over dividend policy on accounting conservatism: Evidence from public firms in Indonesia, Research Journal of Finance and Accounting, 4(6), 146-155.

Renneboog, L., Szilagyi, P.G., 2015. How relevant is dividend policy under low shareholder protection? Journal of International Financial Markets, Institutions and Money. https://doi.org/10.1016/j.intfin.2015.01.006, forthcoming.

Rozeff, M. S., 1982. Growth, beta and agency costs as determinants of dividend payout ratios. Journal of Financial Research, 5 (3), 249-259.

Sato, Y., 2004. Corporate governance in Indonesia: A study on governance of business groups, in, Shimomura Y., (Ed.), The role of governance in Asia. Institute of Southeast Asian Studies. Singapore, pp. 88-136.

Sawicki, J., 2009. Corporate governance and dividend policy in Southeast Asia pre- and post-crisis. European Journal of Finance, 15 (2), 211-230.

Schooley, D. K., Barney Jr, L. D., 1994. Using dividend policy and managerial ownership to reduce agency costs. Journal of Financial Research, 17 (3), 363-73.

Setiawan, D., Bandi, B., Phua, L.K., Trinugroho, I., 2016. Ownership structure and dividend policy in Indonesia. Journal of Asia Business Studies 10 (3), 230-252 .

Setiawan, D., Phua, L.K., 2013. Corporate governance and dividend policy in Indonesia. Business Strategy Series, 14 (5/6), 135-143.

Shleifer, A., Vishny, R. W., 1986. Large shareholders and corporate control. Journal of Political Economy, 94, 461-488.

Shleifer, A., Vishny, R. W., 1997. A survey of corporate governance. Journal of Finance, 52 (2), 737-783.

Short, H., Zhang, H., Keasey, K., 2002. The link between dividend policy and institutional ownership. Journal of Corporate Finance, 8 (2), 105-122.

Smith, C. W., Watts, R. L., 1992. The investment opportunity set and corporate financing, dividend, and compensation policies. Journal of Financial Economics, 32 (3), 263-292. 
Tran, Q.T., Alphonse, P., Nguyen, X.M., 2017. Dividend policy: shareholder rights and creditor rights under the impact of the global financial crisis. Economic Modelling, 64, 502-512.

Wardhana, L. I., Tandelilin, E., Lantara, I.W.N., Junarsin, E., 2014. Dividend policy in Indonesia: a life-cycle explanation. http://dx.doi.org/10.2139/ssrn.2396267.

Wei, J. G., Zhang, W., Xiao, J. Z., 2004. Dividend payment and ownership structure in China. Advances in Financial Economics, 9, 187-219. 


\section{Appendix}

Table A1.

The definition of variables and expected association between dependent and explanatory variables

\begin{tabular}{|c|c|c|}
\hline Variable & Definition & Sign \\
\hline Payer & Dummy variable: 1 if the firm paid dividends in the year; 0 , otherwise. & NA \\
\hline DPS & The ratio of total dividends (in Indonesian Rupiah) to total number of shares. & NA \\
\hline DIVTA & The ratio of total dividends to total assets. & NA \\
\hline DPR & Dividend Payout Ratio: the ratio of total dividends to net income. & NA \\
\hline Family ownership 1 & Percentage of shares held by family members. & - \\
\hline Family ownership 2 & Dummy variable: 1 if family ownership is at least $10 \%$; 0 , otherwise. & - \\
\hline Family ownership 3 & Dummy variable: 1 if family ownership is at least $20 \%$; 0 , otherwise. & - \\
\hline Controlling family & Dummy variable: 1 if the largest shareholder is a family member; 0 , otherwise. & - \\
\hline State ownership 1 & Percentage of shares held by the State. & + \\
\hline State ownership 2 & Dummy variable: 1 if there is State ownership; 0, otherwise. & + \\
\hline Controlling State & Dummy variable: 1 if the largest shareholder is the State; 0 , otherwise. & + \\
\hline Agency conflict & Inverse of the asset turnover: the ratio of assets to sales & - \\
\hline Degree of concentration & $\begin{array}{l}\text { The sum of the proportion of the first and second largest shareholders. Higher } \\
\text { values imply higher concentration. }\end{array}$ & - \\
\hline High concentration & $\begin{array}{l}\text { Dummy variable: } 1 \text { if the degree of concentration is larger than the median } \\
\text { value of the sample companies; } 0 \text {, otherwise. }\end{array}$ & - \\
\hline Second largest & Percentage of shares held by the second largest shareholder. & + \\
\hline First second & $\begin{array}{l}\text { The difference between the percentage of shares held by the first and second } \\
\text { largest shareholder. Higher values imply less competition in affecting the } \\
\text { firm's decision. }\end{array}$ & - \\
\hline Foreign ownership 1 & Percentage of shares held by foreign shareholders. & + \\
\hline Foreign ownership 2 & Dummy variable: 1 if there is foreign ownership; 0, otherwise. & + \\
\hline Controlling foreign & Dummy variable: 1 if the largest shareholder is a foreigner; 0 , otherwise. & + \\
\hline Board size & The number of directors on the board. & + \\
\hline Board Independence & The proportion of outside commissioners on the board. & + \\
\hline Duality & $\begin{array}{l}\text { Dummy variable: } 1 \text { if the same person is the firm's both CEO and Chairman; } \\
0 \text {, otherwise. }\end{array}$ & + \\
\hline Group affiliation & $\begin{array}{l}\text { Dummy variable: } 1 \text { if the firm is affiliated with a group of business; } 0 \text {, } \\
\text { otherwise. }\end{array}$ & - \\
\hline Size & $\begin{array}{l}\text { The natural logarithm of deflated book value of total assets (in trillion } \\
\text { Indonesian rupiahs, IDR10,223.16/USD). }\end{array}$ & + \\
\hline Price to book & Market value of equity divided by book value of equity. & - \\
\hline Growth & The percentage change in the sales between 2012 and 2013. & - \\
\hline Leverage & Book value of total debt divided by total assets. & - \\
\hline Profitability & Return on assets (ROA): the ratio of net income to total assets. & + \\
\hline
\end{tabular}


Table A2. Correlation matrix

\begin{tabular}{|c|c|c|c|c|c|c|c|c|c|c|c|c|c|c|c|c|c|c|c|c|c|c|c|c|c|c|c|c|}
\hline & & (1) & (2) & (3) & (4) & (5) & (6) & (7) & (8) & (9) & (10) & (11) & (12) & (13) & (14) & (15) & (16) & (17) & (18) & (19) & (20) & (21) & (22) & (23) & (24) & (25) & (26) & (27) \\
\hline Payer & (1) & 1 & & & & & & & & & & & & & & & & & & & & & & & & & & \\
\hline DPS & (2) & $0.743^{*}$ & 1 & & & & & & & & & & & & & & & & & & & & & & & & & \\
\hline DIVTA & (3) & 0.477 & $0.642^{*}$ & 1 & & & & & & & & & & & & & & & & & & & & & & & & \\
\hline DPR & (4) & $0.728^{*}$ & $0.685^{*}$ & $0.577^{*}$ & 1 & & & & & & & & & & & & & & & & & & & & & & & \\
\hline Family ownership 1 & (5) & 0.049 & -0.047 & -0.049 & 0.075 & 1 & & & & & & & & & & & & & & & & & & & & & & \\
\hline Family ownership 2 & (6) & 0.070 & 0.040 & -0.033 & 0.130 & $0.807^{*}$ & 1 & & & & & & & & & & & & & & & & & & & & & \\
\hline Family ownership 3 & (7) & 0.031 & -0.010 & -0.039 & 0.056 & $0.788^{*}$ & $0.671^{*}$ & 1 & & & & & & & & & & & & & & & & & & & & \\
\hline Controlling family & (8) & -0.005 & -0.054 & -0.063 & 0.004 & $0.717^{*}$ & $0.746^{*}$ & $0.600^{*}$ & 1 & & & & & & & & & & & & & & & & & & & \\
\hline State ownership 2 & (10) & 0.118 & 0.209 & 0.134 & 0.098 & -0.066 & -0.071 & -0.057 & -0.064 & $0.954^{*}$ & 1 & & & & & & & & & & & & & & & & & \\
\hline Controlling State & (11) & 0.155 & 0.244 & 0.157 & 0.126 & -0.061 & -0.066 & -0.053 & -0.060 & $0.985^{*}$ & $0.933^{*}$ & 1 & & & & & & & & & & & & & & & & \\
\hline Agency conflict & (12) & 0.178 & 0.196 & 0.189 & 0.128 & 0.053 & 0.035 & 0.013 & 0.027 & -0.013 & -0.022 & -0.009 & 1 & & & & & & & & & & & & & & & \\
\hline Degree of concentration & (13) & 0.135 & 0.211 & 0.163 & 0.125 & -0.158 & -0.182 & -0.185 & -0.193 & 0.210 & 0.166 & 0.219 & 0.082 & 1 & & & & & & & & & & & & & & \\
\hline High concentration & (14) & 0.047 & 0.074 & 0.109 & 0.089 & -0.037 & -0.067 & -0.062 & -0.087 & 0.087 & 0.040 & 0.071 & 0.082 & $0.611^{*}$ & 1 & & & & & & & & & & & & & \\
\hline Second largest & (15) & 0.107 & 0.198 & 0.126 & 0.071 & -0.127 & -0.132 & -0.125 & -0.179 & 0.130 & 0.116 & 0.155 & -0.046 & 0.494 & -0.048 & 1 & & & & & & & & & & & & \\
\hline First second & (16) & 0.144 & 0.151 & 0.131 & 0.124 & -0.076 & -0.105 & -0.085 & -0.054 & 0.213 & 0.183 & 0.212 & 0.135 & $0.721^{*}$ & $0.555^{*}$ & -0.141 & 1 & & & & & & & & & & & \\
\hline Foreign ownership1 & (17) & 0.003 & 0.049 & 0.044 & 0.068 & -0.074 & -0.058 & -0.011 & -0.167 & -0.147 & -0.127 & -0.146 & 0.117 & 0.074 & 0.186 & -0.025 & 0.022 & 1 & & & & & & & & & & \\
\hline Foreign ownership 2 & (18) & -0.014 & -0.027 & -0.034 & 0.019 & -0.036 & -0.056 & -0.003 & -0.169 & -0.168 & -0.149 & -0.161 & 0.048 & -0.129 & 0.001 & -0.040 & -0.189 & $0.783^{*}$ & 1 & & & & & & & & & \\
\hline Board size & (20) & 0.339 & 0.396 & 0.215 & 0.235 & -0.067 & -0.078 & -0.026 & -0.095 & 0.158 & 0.153 & 0.160 & -0.010 & 0.173 & 0.080 & 0.169 & 0.106 & 0.087 & 0.053 & 0.095 & 1 & & & & & & & \\
\hline Board independence & (21) & -0.101 & -0.094 & -0.037 & -0.058 & -0.051 & -0.022 & -0.040 & -0.075 & -0.030 & -0.029 & -0.032 & -0.048 & -0.020 & 0.034 & -0.027 & -0.012 & -0.038 & 0.029 & -0.041 & -0.046 & 1 & & & & & & \\
\hline Duality & (22) & 0.003 & -0.051 & -0.051 & -0.004 & 0.287 & 0.194 & 0.251 & 0.304 & -0.029 & -0.030 & -0.028 & 0.070 & 0.005 & -0.038 & 0.038 & 0.029 & -0.097 & -0.124 & -0.063 & -0.070 & 0.030 & 1 & & & & & \\
\hline Group affiliation & (23) & 0.052 & 0.043 & 0.039 & 0.047 & -0.001 & 0.019 & 0.015 & 0.017 & 0.112 & 0.087 & 0.113 & -0.172 & -0.012 & -0.036 & 0.007 & 0.006 & -0.156 & -0.128 & -0.122 & 0.124 & -0.054 & 0.073 & 1 & & & & \\
\hline Size & (24) & 0.244 & 0.308 & 0.110 & 0.138 & -0.188 & -0.181 & -0.145 & -0.179 & 0.245 & 0.230 & 0.256 & -0.184 & 0.107 & -0.084 & 0.192 & 0.040 & -0.007 & 0.017 & -0.013 & 0.555 & 0.028 & -0.041 & 0.214 & 1 & & & \\
\hline Price to book & (25) & 0.199 & 0.159 & 0.278 & 0.127 & 0.218 & 0.111 & 0.170 & 0.138 & 0.022 & 0.019 & 0.030 & 0.099 & -0.002 & -0.027 & 0.024 & 0.024 & -0.040 & -0.010 & -0.030 & 0.072 & 0.042 & 0.012 & -0.045 & 0.038 & 1 & & \\
\hline Growth & (26) & -0.030 & -0.025 & -0.048 & -0.046 & 0.028 & -0.022 & 0.013 & -0.015 & 0.028 & 0.030 & 0.027 & -0.105 & -0.058 & -0.106 & -0.020 & -0.050 & -0.097 & -0.062 & -0.088 & 0.126 & -0.057 & -0.029 & 0.111 & 0.174 & 0.023 & 1 & \\
\hline Leverage & (27) & -0.146 & -0.141 & -0.133 & -0.065 & -0.045 & -0.086 & -0.068 & -0.052 & 0.016 & 0.026 & 0.012 & 0.197 & -0.087 & -0.077 & -0.066 & -0.037 & -0.012 & 0.000 & -0.009 & -0.005 & 0.030 & -0.011 & 0.011 & 0.092 & -0.023 & -0.062 & 1 \\
\hline Profitability & (28) & 0.426 & 0.454 & $0.541^{*}$ & 0.223 & 0.015 & 0.045 & 0.032 & 0.023 & 0.095 & 0.096 & 0.108 & 0.148 & 0.089 & 0.029 & 0.086 & 0.070 & -0.022 & -0.025 & 0.011 & 0.237 & -0.042 & -0.031 & 0.012 & 0.144 & 0.240 & 0.159 & -0.356 \\
\hline
\end{tabular}
Notes:

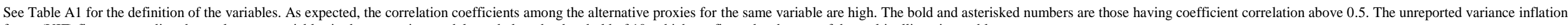
factor (VIF) figures regarding the explanatory variables in the regression models are below the threshold of 10, which confirms the absence of the multicollinearity problem. 
Table 1. Descriptive statistics

\begin{tabular}{|c|c|c|c|c|}
\hline & Minimum & Maximum & Mean & S.D. \\
\hline Payer & 0.000 & 1.000 & 0.469 & 0.501 \\
\hline DPS & 0.000 & 817.000 & 28.322 & 80.747 \\
\hline DIVTA & 0.000 & 0.940 & 0.016 & 0.059 \\
\hline DPR & 0.000 & 0.871 & 0.134 & 0.195 \\
\hline Family ownership 1 & 0.000 & 0.950 & 0.036 & 0.119 \\
\hline Family ownership 2 & 0.000 & 1.000 & 0.102 & 0.303 \\
\hline Family ownership 3 & 0.000 & 1.000 & 0.055 & 0.229 \\
\hline Controlling family & 0.000 & 1.000 & 0.076 & 0.255 \\
\hline State ownership 1 & 0.000 & 0.900 & 0.029 & 0.135 \\
\hline State ownership 2 & 0.000 & 1.000 & 0.047 & 0.211 \\
\hline Controlling State & 0.000 & 1.000 & 0.041 & 0.205 \\
\hline Agency conflict & 0.547 & 6.816 & 2.307 & 2.001 \\
\hline Degree of concentration & 0.140 & 0.995 & 0.606 & 0.201 \\
\hline High concentration & 0.000 & 1.000 & 0.485 & 0.500 \\
\hline Second largest & 0.000 & 0.490 & 0.175 & 0.115 \\
\hline First second & 0.000 & 0.850 & 0.225 & 0.235 \\
\hline Foreign ownership1 & 0.000 & 0.960 & 0.193 & 0.275 \\
\hline Foreign ownership 2 & 0.000 & 1.000 & 0.445 & 0.498 \\
\hline Controlling foreign & 0.000 & 1.000 & 0.176 & 0.375 \\
\hline Board size & 1.000 & 14.000 & 3.811 & 2.016 \\
\hline Board independence & 0.000 & 1.000 & 0.408 & 0.148 \\
\hline Duality & 0.000 & 1.000 & 0.016 & 0.131 \\
\hline Group affiliation & 0.000 & 1.000 & 0.768 & 0.414 \\
\hline Size & 9.380 & 18.670 & 14.502 & 1.696 \\
\hline Price to book & 0.090 & 11.270 & 1.979 & 1.905 \\
\hline Growth & -0.460 & 2.163 & 0.204 & 0.451 \\
\hline Leverage & 0.040 & 0.990 & 0.473 & 0.214 \\
\hline Profitability & -1.530 & 0.391 & 0.037 & 0.109 \\
\hline
\end{tabular}


Table 2. The ranges of share ownership held by the largest shareholders for Indonesian firms in 2013.

\begin{tabular}{cccc}
\hline Range of Ownership (\%) & Firms & Percentage & $\begin{array}{c}\text { Cumulative } \\
\text { Percentage }\end{array}$ \\
\hline $90-100$ & 7 & 1.90 & 1.90 \\
$80-89.99$ & 20 & 5.42 & 7.32 \\
$70-79.99$ & 28 & 7.59 & 14.91 \\
$60-69.99$ & 46 & 12.47 & 27.38 \\
$50-59.99$ & 52 & 14.09 & 41.47 \\
$40-49.99$ & 60 & 16.26 & 57.73 \\
$30-39.99$ & 63 & 17.07 & 74.80 \\
$20-29.99$ & 53 & 14.36 & 89.16 \\
$10-19.99$ & 34 & 9.21 & 98.37 \\
$0-9.99$ & 6 & 1.63 & 100.00 \\
\hline Total & $\mathbf{3 6 9}$ & $\mathbf{1 0 0}$ & \\
\hline
\end{tabular}

Notes:

The largest shareholder is defined as the shareholder who has the firm's highest proportion of stocks in terms of the number of shares held. The first column shows range of ownership held by the largest shareholders. For the range between $90-100 \%$, this means there are 7 firms in which its largest shareholder has at least $90 \%$ of stocks. Similarly, for the last line, there are 6 firms in which the largest shareholder holds less than $10 \%$ of stocks.

Table 3. The number of firms and the overview of dividend policy in each industry classification.

\begin{tabular}{lcccccc}
\hline Industry & Payer & $\begin{array}{c}\text { Non- } \\
\text { Payer }\end{array}$ & $\begin{array}{c}\text { Number of } \\
\text { firms }\end{array}$ & $\begin{array}{c}\text { Proportion of } \\
\text { firms }\end{array}$ & $\begin{array}{c}\text { Proportion of } \\
\text { payers (\%) }\end{array}$ & $\begin{array}{c}\text { Mean DPS for } \\
\text { payers (IDR) }\end{array}$ \\
\hline Agriculture & 10 & 5 & 15 & 4.07 & 66.67 & 42.26 \\
Mining & 13 & 23 & 36 & 9.76 & 36.11 & 58.51 \\
Basic Industry & 25 & 33 & 58 & 15.72 & 43.10 & 105.74 \\
Miscellaneous Industry & 17 & 21 & 38 & 10.30 & 44.74 & 95.01 \\
Consumer Goods & 17 & 14 & 31 & 8.40 & 54.84 & 137.58 \\
Property \&Real Estate & 27 & 24 & 51 & 13.82 & 52.94 & 21.01 \\
Infrastructure & 17 & 25 & 42 & 11.38 & 40.48 & 53.14 \\
Trade \&Service & 47 & 51 & 98 & 26.56 & 47.96 & 32.02 \\
\hline Total & $\mathbf{1 7 3}$ & $\mathbf{1 9 6}$ & $\mathbf{3 6 9}$ & $\mathbf{1 0 0 . 0 0}$ & & \\
\hline
\end{tabular}

Notes:

This table exhibits the number of payer and non-payer firms for each industry. The Financial Service Authority classifies IDX firms into nine different industries; financial industry is excluded as sample of this study. Payers account for $47 \%$ of sample compared to $53 \%$ of non-payers. Last column shows mean of dividend per share in Indonesian rupiah, and firms in consumers goods industry. 
Table 4. Probit regressions for the propensity to pay dividends.

\begin{tabular}{|c|c|c|c|c|c|c|c|c|}
\hline \multirow[b]{3}{*}{ Family ownership 1} & \multicolumn{4}{|c|}{ Panel A. Managers-shareholders conflict } & \multicolumn{4}{|c|}{ Panel B. Major-minor shareholders conflict } \\
\hline & $(1)$ & (2) & (3) & (4) & (5) & (6) & (7) & $(8)$ \\
\hline & $\begin{array}{c}0.255 \\
(0.339)\end{array}$ & - & - & - & $\begin{array}{c}0.110 \\
(0.283)\end{array}$ & - & - & - \\
\hline Family ownership 2 & - & $\begin{array}{c}0.156 \\
(0.106)\end{array}$ & - & - & - & $\begin{array}{c}0.109 \\
(0.102)\end{array}$ & - & - \\
\hline Family ownership 3 & - & - & $\begin{array}{l}0.0879 \\
(0.143)\end{array}$ & - & - & - & $\begin{array}{c}0.013 \\
(0.130)\end{array}$ & - \\
\hline Controlling family & - & - & - & $\begin{array}{l}0.0067 \\
(0.130)\end{array}$ & - & - & - & $\begin{array}{c}0.007 \\
(0.120)\end{array}$ \\
\hline State ownership 1 & $\begin{array}{c}0.124 \\
(0.274)\end{array}$ & - & - & - & $\begin{array}{c}0.389 \\
(0.271)\end{array}$ & - & - & - \\
\hline State ownership 2 & - & $\begin{array}{c}0.038 \\
(0.150)\end{array}$ & - & - & - & $\begin{array}{c}0.207 \\
(0.132)\end{array}$ & - & - \\
\hline Controlling State & - & - & $\begin{array}{c}0.129 \\
(0.176)\end{array}$ & $\begin{array}{c}0.129 \\
(0.176)\end{array}$ & - & - & $\begin{array}{c}0.304 * * \\
(0.140)\end{array}$ & $\begin{array}{c}0.293^{* * *} \\
(0.146)\end{array}$ \\
\hline Agency conflict & $\begin{array}{c}-0.087 * * * \\
(0.021)\end{array}$ & $\begin{array}{c}-0.088 * * * \\
(0.021)\end{array}$ & $\begin{array}{c}-0.0884 * * * \\
(0.0218)\end{array}$ & $\begin{array}{c}-0.0876 * * * \\
(0.0216)\end{array}$ & - & - & - & - \\
\hline Degree of concentration & - & - & - & - & $\begin{array}{c}0.075 \\
(0.121)\end{array}$ & - & - & - \\
\hline High concentration & - & - & - & - & - & $\begin{array}{c}-0.006 \\
(0.0607)\end{array}$ & - & - \\
\hline Second largest & - & - & - & - & - & - & $\begin{array}{c}0.175 \\
(0.246)\end{array}$ & - \\
\hline First second & - & - & - & - & - & - & - & $\begin{array}{c}0.063 \\
(0.110)\end{array}$ \\
\hline Foreign ownership 1 & $\begin{array}{l}-0.049 \\
(0.123)\end{array}$ & - & - & - & $\begin{array}{l}-0.001 \\
(0.107)\end{array}$ & - & - & - \\
\hline Foreign ownership 2 & - & $\begin{array}{l}-0.041 \\
(0.069)\end{array}$ & - & - & - & $\begin{array}{l}-0.004 \\
(0.059)\end{array}$ & - & - \\
\hline Controlling Foreign & - & - & $\begin{array}{l}-0.0335 \\
(0.0857)\end{array}$ & $\begin{array}{l}-0.0290 \\
(0.0872)\end{array}$ & - & - & $\begin{array}{c}0.040 \\
(0.076)\end{array}$ & $\begin{array}{c}0.035 \\
(0.079)\end{array}$ \\
\hline Board size & $\begin{array}{c}0.054 * * * \\
(0.020)\end{array}$ & $\begin{array}{c}0.053 * * \\
(0.020)\end{array}$ & $\begin{array}{c}0.0530 * * \\
(0.0208)\end{array}$ & $\begin{array}{c}0.0548 * * * \\
(0.0210)\end{array}$ & $\begin{array}{c}0.071 * * * \\
(0.0183)\end{array}$ & $\begin{array}{c}0.075^{* * * *} \\
(0.018)\end{array}$ & $\begin{array}{c}0.073 * * * \\
(0.018)\end{array}$ & $\begin{array}{c}0.074 * * * \\
(0.018)\end{array}$ \\
\hline Board independence & $\begin{array}{l}-0.331 \\
(0.255)\end{array}$ & $\begin{array}{l}-0.332 \\
(0.260)\end{array}$ & $\begin{array}{l}-0.339 \\
(0.255)\end{array}$ & $\begin{array}{l}-0.341 \\
(0.256)\end{array}$ & $\begin{array}{l}-0.080 \\
(0.216)\end{array}$ & $\begin{array}{l}-0.088 \\
(0.216)\end{array}$ & $\begin{array}{l}-0.076 \\
(0.216)\end{array}$ & $\begin{array}{l}-0.074 \\
(0.216)\end{array}$ \\
\hline Duality & $\begin{array}{l}-0.040 \\
(0.253)\end{array}$ & $\begin{array}{l}-0.064 \\
(0.251)\end{array}$ & $\begin{array}{c}-0.0103 \\
(0.247)\end{array}$ & $\begin{array}{l}0.0198 \\
(0.247)\end{array}$ & $\begin{array}{c}0.113 \\
(0.222)\end{array}$ & $\begin{array}{c}0.088 \\
(0.227)\end{array}$ & $\begin{array}{c}0.136 \\
(0.224)\end{array}$ & $\begin{array}{c}0.139 \\
(0.221)\end{array}$ \\
\hline Group affiliation & $\begin{array}{c}0.073 \\
(0.083)\end{array}$ & $\begin{array}{l}0.0691 \\
(0.083)\end{array}$ & $\begin{array}{c}0.0734 \\
(0.0837)\end{array}$ & $\begin{array}{c}0.0746 \\
(0.0835)\end{array}$ & $\begin{array}{c}0.070 \\
(0.073)\end{array}$ & $\begin{array}{c}0.068 \\
(0.073)\end{array}$ & $\begin{array}{c}0.073 \\
(0.074)\end{array}$ & $\begin{array}{c}0.070 \\
(0.073)\end{array}$ \\
\hline Size & $\begin{array}{c}0.064 * * \\
(0.026)\end{array}$ & $\begin{array}{c}0.068 * * * \\
(0.026)\end{array}$ & $\begin{array}{c}0.0621^{* *} * \\
(0.0262)\end{array}$ & $\begin{array}{c}0.0586 * * \\
(0.0261)\end{array}$ & $\begin{array}{l}0.037^{*} \\
(0.020)\end{array}$ & $\begin{array}{c}0.041 * * \\
(0.021)\end{array}$ & $\begin{array}{l}0.033^{*} \\
(0.020)\end{array}$ & $\begin{array}{l}0.036^{*} \\
(0.020)\end{array}$ \\
\hline Price to book & $\begin{array}{c}0.051 * * * \\
(0.020)\end{array}$ & $\begin{array}{c}0.052 * * * \\
(0.019)\end{array}$ & $\begin{array}{c}0.0534 * * * \\
(0.0193)\end{array}$ & $\begin{array}{c}0.0555^{* * *} * \\
(0.0187)\end{array}$ & $\begin{array}{c}0.035^{* * *} \\
(0.016)\end{array}$ & $\begin{array}{c}0.034 * * \\
(0.016)\end{array}$ & $\begin{array}{c}0.0355^{* * *} \\
(0.015)\end{array}$ & $\begin{array}{c}0.035^{* * *} \\
(0.015)\end{array}$ \\
\hline Growth & $\begin{array}{l}-0.264^{*} \\
(0.137)\end{array}$ & $\begin{array}{l}-0.259^{*} \\
(0.135)\end{array}$ & $\begin{array}{c}-0.255^{*} \\
(0.135)\end{array}$ & $\begin{array}{l}-0.250^{*} \\
(0.132)\end{array}$ & $\begin{array}{c}-0.351 * * * \\
(0.124)\end{array}$ & $\begin{array}{c}-0.359 * * * \\
(0.128)\end{array}$ & $\begin{array}{c}-0.340 * * * * \\
(0.121)\end{array}$ & $\begin{array}{c}-0.343 * * * \\
(0.122)\end{array}$ \\
\hline Leverage & $\begin{array}{l}-0.484^{*} \\
(0.256)\end{array}$ & $\begin{array}{l}-0.476^{*} \\
(0.254)\end{array}$ & $\begin{array}{l}-0.482^{*} \\
(0.254)\end{array}$ & $\begin{array}{l}-0.482^{*} \\
(0.251)\end{array}$ & $\begin{array}{l}-0.226 \\
(0.153)\end{array}$ & $\begin{array}{l}-0.239 \\
(0.154)\end{array}$ & $\begin{array}{l}-0.225 \\
(0.155)\end{array}$ & $\begin{array}{l}-0.234 \\
(0.151)\end{array}$ \\
\hline Profitability & $\begin{array}{c}3.135^{* * * *} \\
(1.05)\end{array}$ & $\begin{array}{c}3.144 * * * \\
(1.044)\end{array}$ & $\begin{array}{c}3.132 * * * \\
(1.061)\end{array}$ & $\begin{array}{c}3.104 * * * \\
(1.031)\end{array}$ & $\begin{array}{c}2.257 * * * \\
(0.695)\end{array}$ & $\begin{array}{c}2.286^{* * * *} \\
(0.702)\end{array}$ & $\begin{array}{c}2.309^{* * * *} \\
(0.703)\end{array}$ & $\begin{array}{c}2.258 * * * \\
(0.690)\end{array}$ \\
\hline $\begin{array}{l}\text { Wald } \chi^{2} \\
\text { Pseudo } R^{2} \\
\text { Prob }>\chi^{2}\end{array}$ & $\begin{array}{c}106.62 \\
0.3208 \\
0.000 \\
\end{array}$ & $\begin{array}{c}105.50 \\
0.3239 \\
0.000 \\
\end{array}$ & $\begin{array}{c}106.15 \\
0.3206 \\
0.000 \\
\end{array}$ & $\begin{array}{c}106.57 \\
0.3198 \\
0.000 \\
\end{array}$ & $\begin{array}{c}88.73 \\
0.2255 \\
0.000 \\
\end{array}$ & $\begin{array}{c}90.53 \\
0.2253 \\
0.000 \\
\end{array}$ & $\begin{array}{c}87.75 \\
0.2278 \\
0.000 \\
\end{array}$ & $\begin{array}{c}87.49 \\
0.2276 \\
0.000 \\
\end{array}$ \\
\hline
\end{tabular}

This table shows the results of marginal effect regressions for the tendency to pay dividends from the data consisting 369 firms, where the dependent variable is Payer. Panel A reports the probit coefficients in the context of managers-shareholders conflicts of interest; Panel B reports the probit coefficients in the context of major-minor shareholders conflict of interest. In Panel A, Agency conflict variable is based on the asset turnover ratio while in Panel B it is based on Degree of concentration, High concentration, Second largest and First second. In Panel B, none of the proxies for the conflicts is significant, but in Panel A Agency conflict reveals highly significant results. Board size is the only significant variable of corporate governance related factors. Regarding firm-specific controlling variables, Panel A shows that all the variables are significant while Panel B shows that Leverage is the only insignificant variable. Robust heteroscedasticity-consistent standard errors are in the parentheses. $* p<0.1 ; * * p<0.05$; *** $p<0.01$. Industry dummies are included in all models. See Table A1 for the definition of the variables. 
Table 5. OLS regressions for the level of dividend payment: managers and shareholders conflicts of interest

\begin{tabular}{|c|c|c|c|c|c|c|c|c|c|c|c|c|}
\hline \multirow[b]{3}{*}{ Family ownership 1} & \multicolumn{4}{|c|}{ Panel A. Dependent variable: DPS } & \multicolumn{4}{|c|}{ Panel B. Dependent variable: DIVTA } & \multicolumn{4}{|c|}{ Panel C. Dependent variable: DPR } \\
\hline & (1) & (2) & (3) & (4) & (5) & (6) & (7) & (8) & (9) & $(10)$ & (11) & (12) \\
\hline & $\begin{array}{l}-0.328 \\
(0.322)\end{array}$ & - & - & - & $\begin{array}{c}-0.024 * * \\
(0.009)\end{array}$ & 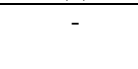 & - & - & $\begin{array}{c}0.114 \\
(0.129)\end{array}$ & 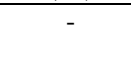 & - & - \\
\hline Family ownership 2 & - & $\begin{array}{c}0.143 \\
(0.144)\end{array}$ & - & - & - & $\begin{array}{c}-0.0057^{*} \\
(0.0034)\end{array}$ & - & - & - & $\begin{array}{l}0.085^{*} \\
(0.050)\end{array}$ & - & - \\
\hline Family ownership 3 & - & - & $\begin{array}{l}-0.026 \\
(0.174)\end{array}$ & - & - & - & $\begin{array}{c}-0.009 * * \\
(0.004)\end{array}$ & - & - & - & $\begin{array}{c}0.032 \\
(0.052)\end{array}$ & - \\
\hline Controlling family & - & - & - & $\begin{array}{l}-0.047 \\
(0.164)\end{array}$ & - & - & - & $\begin{array}{c}-0.0072 * \\
(0.0040)\end{array}$ & - & - & - & $\begin{array}{c}0.016 \\
(0.046)\end{array}$ \\
\hline State ownership 1 & $\begin{array}{c}0.681 * * \\
(0.341)\end{array}$ & - & - & - & $\begin{array}{c}0.015 \\
(0.009)\end{array}$ & - & - & - & $\begin{array}{c}0.110 \\
(0.0714)\end{array}$ & - & - & - \\
\hline State ownership 2 & - & $\begin{array}{l}0.351 * \\
(0.191)\end{array}$ & - & - & - & $\begin{array}{c}0.0081 \\
(0.0054)\end{array}$ & - & - & - & $\begin{array}{c}0.049 \\
(0.039)\end{array}$ & - & - \\
\hline Controlling State & - & - & $\begin{array}{c}0.498^{* *} \\
(0.199)\end{array}$ & $\begin{array}{c}0.496^{* * *} \\
(0.199)\end{array}$ & - & - & $\begin{array}{l}0.011^{*} \\
(0.006)\end{array}$ & $\begin{array}{c}0.0109^{*} \\
(0.006)\end{array}$ & - & - & $\begin{array}{l}0.073 * \\
(0.041)\end{array}$ & $\begin{array}{l}0.074 * \\
(0.041)\end{array}$ \\
\hline Agency conflict & $\begin{array}{c}-0.063 * * * \\
(0.015)\end{array}$ & $\begin{array}{c}-0.065 * * * * \\
(0.015)\end{array}$ & $\begin{array}{c}-0.061 * * * * \\
(0.015)\end{array}$ & $\begin{array}{c}-0.062 * * * \\
(0.015)\end{array}$ & $\begin{array}{l}-0.0008 \\
(0.0005)\end{array}$ & $\begin{array}{c}-0.0008^{*} \\
(0.0005)\end{array}$ & $\begin{array}{l}-0.0007 \\
(0.0005)\end{array}$ & $\begin{array}{l}-0.0008 \\
(0.0005)\end{array}$ & $\begin{array}{c}-0.011 * * * \\
(0.004)\end{array}$ & $\begin{array}{c}-0.012 * * * \\
(0.004)\end{array}$ & $\begin{array}{c}-0.0117 * * * \\
(0.004)\end{array}$ & $\begin{array}{c}-0.011 \text { ** } \\
(0.004)\end{array}$ \\
\hline Foreign ownership 1 & $\begin{array}{c}0.046 \\
(0.153)\end{array}$ & - & - & - & $\begin{array}{c}0.0045 \\
(0.0049)\end{array}$ & - & - & - & $\begin{array}{c}0.036 \\
(0.039)\end{array}$ & - & - & - \\
\hline Foreign ownership 2 & - & $\begin{array}{l}-0.060 \\
(0.076)\end{array}$ & - & - & - & $\begin{array}{l}-0.0007 \\
(0.0025)\end{array}$ & - & - & - & $\begin{array}{c}0.004 \\
(0.020)\end{array}$ & - & - \\
\hline Controlling foreign & - & - & $\begin{array}{c}0.100 \\
(0.111)\end{array}$ & $\begin{array}{c}0.095 \\
(0.111)\end{array}$ & - & - & $\begin{array}{c}0.003 \\
(0.003)\end{array}$ & $\begin{array}{c}0.0028 \\
(0.0032)\end{array}$ & - & - & $\begin{array}{c}0.034 \\
(0.027)\end{array}$ & $\begin{array}{c}0.036 \\
(0.028)\end{array}$ \\
\hline Board size & $\begin{array}{c}0.081 * * * \\
(0.023)\end{array}$ & $\begin{array}{c}0.081 * * * \\
(0.023)\end{array}$ & $\begin{array}{c}0.079 * * * \\
(0.023)\end{array}$ & $\begin{array}{c}0.079 * * * \\
(0.023)\end{array}$ & $\begin{array}{c}0.0014 * * \\
(0.0006)\end{array}$ & $\begin{array}{c}0.0014 * * \\
(0.0006)\end{array}$ & $\begin{array}{c}0.0014 * * \\
(0.0006)\end{array}$ & $\begin{array}{c}0.0013^{* *} \\
(0.0006)\end{array}$ & $\begin{array}{c}0.014 * * \\
(0.006)\end{array}$ & $\begin{array}{c}0.015^{* *} \\
(0.006)\end{array}$ & $\begin{array}{l}0.014 * * \\
(0.006)\end{array}$ & $\begin{array}{c}0.014 * * \\
(0.006)\end{array}$ \\
\hline Board independence & $\begin{array}{l}-0.387 \\
(0.236)\end{array}$ & $\begin{array}{l}-0.364 \\
(0.245)\end{array}$ & $\begin{array}{l}-0.360 \\
(0.235)\end{array}$ & $\begin{array}{l}-0.367 \\
(0.237)\end{array}$ & $\begin{array}{l}-0.006 \\
(0.009)\end{array}$ & $\begin{array}{l}-0.006 \\
(0.009)\end{array}$ & $\begin{array}{l}-0.006 \\
(0.009)\end{array}$ & $\begin{array}{l}-0.006 \\
(0.009)\end{array}$ & $\begin{array}{l}-0.028 \\
(0.080)\end{array}$ & $\begin{array}{c}-0.034 \\
(0.081)\end{array}$ & $\begin{array}{l}-0.028 \\
(0.080)\end{array}$ & $\begin{array}{l}-0.028 \\
(0.081)\end{array}$ \\
\hline Duality & $\begin{array}{l}-0.195 \\
(0.292)\end{array}$ & $\begin{array}{l}-0.359 \\
(0.314)\end{array}$ & $\begin{array}{l}-0.245 \\
(0.303)\end{array}$ & $\begin{array}{l}-0.229 \\
(0.305)\end{array}$ & $\begin{array}{l}-0.003 \\
(0.006)\end{array}$ & $\begin{array}{l}-0.008 \\
(0.005)\end{array}$ & $\begin{array}{l}-0.005 \\
(0.006)\end{array}$ & $\begin{array}{l}-0.005 \\
(0.005)\end{array}$ & $\begin{array}{l}-0.028 \\
(0.068)\end{array}$ & $\begin{array}{l}-0.041 \\
(0.074)\end{array}$ & $\begin{array}{l}-0.018 \\
(0.072)\end{array}$ & $\begin{array}{l}-0.013 \\
(0.074)\end{array}$ \\
\hline Group affiliation & $\begin{array}{c}0.079 \\
(0.105)\end{array}$ & $\begin{array}{c}0.064 \\
(0.105)\end{array}$ & $\begin{array}{c}0.078 \\
(0.105)\end{array}$ & $\begin{array}{c}0.078 \\
(0.105)\end{array}$ & $\begin{array}{c}0.0059^{* *} \\
(0.0028)\end{array}$ & $\begin{array}{l}0.005^{* *} \\
(0.002)\end{array}$ & $\begin{array}{c}0.0057^{* *} \\
(0.002)\end{array}$ & $\begin{array}{c}0.0056^{* *} \\
(0.002)\end{array}$ & $\begin{array}{c}0.028 \\
(0.024)\end{array}$ & $\begin{array}{c}0.024 \\
(0.024)\end{array}$ & $\begin{array}{c}0.028 \\
(0.024)\end{array}$ & $\begin{array}{c}0.028 \\
(0.024)\end{array}$ \\
\hline Size & $\begin{array}{c}0.073 * * * \\
(0.026)\end{array}$ & $\begin{array}{c}0.084 * * * \\
(0.026)\end{array}$ & $\begin{array}{c}0.074 * * * \\
(0.026)\end{array}$ & $\begin{array}{c}0.074 * * * \\
(0.026)\end{array}$ & $\begin{array}{c}0.0001 \\
(0.0008)\end{array}$ & $\begin{array}{c}0.0002 \\
(0.0008)\end{array}$ & $\begin{array}{c}0.0001 \\
(0.0008)\end{array}$ & $\begin{array}{c}0.0001 \\
(0.0008)\end{array}$ & $\begin{array}{c}0.003 \\
(0.006)\end{array}$ & $\begin{array}{l}0.0051 \\
(0.006)\end{array}$ & $\begin{array}{c}0.002 \\
(0.007)\end{array}$ & $\begin{array}{c}0.002 \\
(0.007)\end{array}$ \\
\hline Price to Book & $\begin{array}{l}0.033^{*} \\
(0.018)\end{array}$ & $\begin{array}{c}0.028 \\
(0.018)\end{array}$ & $\begin{array}{c}0.029 \\
(0.018)\end{array}$ & $\begin{array}{c}0.030 \\
(0.018)\end{array}$ & $\begin{array}{c}0.0028^{* * * *} \\
(0.0006)\end{array}$ & $\begin{array}{c}0.0026 * * * \\
(0.0006)\end{array}$ & $\begin{array}{c}0.0027 * * * * \\
(0.0006)\end{array}$ & $\begin{array}{c}0.0026^{* * * *} * \\
(0.0006)\end{array}$ & $\begin{array}{l}0.008^{*} \\
(0.004)\end{array}$ & $\begin{array}{l}0.008^{*} \\
(0.005)\end{array}$ & $\begin{array}{l}0.009^{*} \\
(0.004)\end{array}$ & $\begin{array}{l}0.009^{*} \\
(0.004)\end{array}$ \\
\hline Growth & $\begin{array}{c}-0.246^{* *} \\
(0.096)\end{array}$ & $\begin{array}{c}-0.266^{* * *} \\
(0.102)\end{array}$ & $\begin{array}{c}-0.247 * * \\
(0.098)\end{array}$ & $\begin{array}{c}-0.247 * * \\
(0.097)\end{array}$ & $\begin{array}{c}-0.0107 * * \\
(0.0048)\end{array}$ & $\begin{array}{c}-0.0117 * * \\
(0.0049)\end{array}$ & $\begin{array}{c}-0.011 * * \\
(0.004)\end{array}$ & $\begin{array}{c}-0.011^{* *} \\
(0.004)\end{array}$ & $\begin{array}{l}-0.036 \\
(0.029)\end{array}$ & $\begin{array}{l}-0.036 \\
(0.030)\end{array}$ & $\begin{array}{l}-0.033 \\
(0.029)\end{array}$ & $\begin{array}{l}-0.033 \\
(0.030)\end{array}$ \\
\hline Leverage & $\begin{array}{l}-0.334 \\
(0.218)\end{array}$ & $\begin{array}{l}-0.327 \\
(0.218)\end{array}$ & $\begin{array}{l}-0.325 \\
(0.215)\end{array}$ & $\begin{array}{l}-0.324 \\
(0.216)\end{array}$ & $\begin{array}{c}0.0012 \\
(0.0104)\end{array}$ & $\begin{array}{c}0.0007 \\
(0.0106)\end{array}$ & $\begin{array}{l}0.0012 \\
(0.010)\end{array}$ & $\begin{array}{c}0.0016 \\
(0.0104)\end{array}$ & $\begin{array}{l}-0.063 \\
(0.041)\end{array}$ & $\begin{array}{l}-0.060 \\
(0.042)\end{array}$ & $\begin{array}{l}-0.064 \\
(0.040)\end{array}$ & $\begin{array}{l}-0.066 \\
(0.040)\end{array}$ \\
\hline Profitability & $\begin{array}{c}3.392 * * * \\
(0.784)\end{array}$ & $\begin{array}{c}3.373 * * * \\
(0.790)\end{array}$ & $\begin{array}{c}3.374 * * * \\
(0.780)\end{array}$ & $\begin{array}{c}3.379 * * * \\
(0.780)\end{array}$ & $\begin{array}{c}0.156^{* * * *} \\
(0.044)\end{array}$ & $\begin{array}{c}0.157 * * * \\
(0.046)\end{array}$ & $\begin{array}{c}0.156^{* * * *} \\
(0.044)\end{array}$ & $\begin{array}{c}0.156^{* * *} \\
(0.045)\end{array}$ & $\begin{array}{l}0.256^{*} \\
(0.135)\end{array}$ & $\begin{array}{l}0.241^{*} \\
(0.139)\end{array}$ & $\begin{array}{l}0.246^{*} \\
(0.131)\end{array}$ & $\begin{array}{l}0.245^{*} \\
(0.127)\end{array}$ \\
\hline Constant & $\begin{array}{c}-0.676^{* *} \\
(0.343)\end{array}$ & $\begin{array}{c}-0.816^{* * *} \\
(0.342)\end{array}$ & $\begin{array}{c}-0.705^{* *} \\
(0.344)\end{array}$ & $\begin{array}{c}-0.692^{* * *} \\
(0.344)\end{array}$ & $\begin{array}{c}-0.012 \\
(0.012)\end{array}$ & $\begin{array}{l}-0.013 \\
(0.012)\end{array}$ & $\begin{array}{l}-0.012 \\
(0.012)\end{array}$ & $\begin{array}{l}-0.013 \\
(0.012)\end{array}$ & $\begin{array}{c}0.030 \\
(0.094)\end{array}$ & $\begin{array}{l}0.0055 \\
(0.096)\end{array}$ & $\begin{array}{c}0.050 \\
(0.096)\end{array}$ & $\begin{array}{c}0.055 \\
(0.096)\end{array}$ \\
\hline $\begin{array}{l}\text { R-squared } \\
\text { F (Prob }>F)\end{array}$ & 0.412 & 0.413 & 0.415 & 0.415 & 0.420 & 0.413 & 0.420 & 0.418 & 0.180 & 0.189 & 0.181 & 0.180 \\
\hline$F($ Prob $>F)$ & $13.98 * * *$ & $13.41 * * *$ & $14.20 * * *$ & $14.16^{* * * *}$ & $5.89 * * *$ & $5.91 * * *$ & $5.97 * * *$ & $5.99 * * *$ & $5.75^{* * * *}$ & $5.65^{* * *}$ & $5.90 * * *$ & $5.96 * * *$ \\
\hline
\end{tabular}

Notes. This table shows the results of OLS regressions for the level of dividend payments from data consisting 369 firms. The analyses consider the manager-shareholder conflicts. Robust heteroscedasticity-consistent standard errors are in the parentheses. * $p<0.1 ; * * p<0.05 ; * * * p<0.01$. Industry dummies are included in all models. See Table A1 for the definition of the variables. 
Table 6. OLS regressions for the level of dividend payments: major-minor shareholders conflicts of interest

\begin{tabular}{|c|c|c|c|c|c|c|c|c|c|c|c|c|}
\hline & \multicolumn{4}{|c|}{ Panel A. Dependent variable: DPS } & \multicolumn{4}{|c|}{ Panel B. Dependent variable: DIVTA } & \multicolumn{4}{|c|}{ Panel C. Dependent variable: DPR } \\
\hline & (1) & (2) & (3) & (4) & (5) & $(6)$ & $(7)$ & $(8)$ & (9) & (10) & (11) & (12) \\
\hline Family ownership 1 & $\begin{array}{l}-1.034 \\
(0.665)\end{array}$ & - & - & - & $\begin{array}{c}-0.037 \text { **** } \\
(0.012)\end{array}$ & - & - & - & $\begin{array}{c}0.044 \\
(0.113)\end{array}$ & - & - & - \\
\hline Family ownership 2 & - & $\begin{array}{c}0.168 \\
(0.333)\end{array}$ & - & - & - & $\begin{array}{c}-0.011 * * * \\
(0.004)\end{array}$ & - & - & - & $\begin{array}{c}0.057 \\
(0.048)\end{array}$ & - & - \\
\hline Family ownership 3 & - & - & $\begin{array}{l}-0.161 \\
(0.390)\end{array}$ & - & - & - & $\begin{array}{c}-0.013 * * * \\
(0.005)\end{array}$ & - & - & - & $\begin{array}{c}0.008 \\
(0.053)\end{array}$ & - \\
\hline Controlling family & - & - & - & $\begin{array}{l}-0.173 \\
(0.345)\end{array}$ & - & - & - & $\begin{array}{c}-0.011 * * \\
(0.004)\end{array}$ & - & - & - & $\begin{array}{c}0.00003 \\
(0.043)\end{array}$ \\
\hline State ownership 1 & $\begin{array}{c}2.023 * * * \\
(0.763)\end{array}$ & - & - & - & $\begin{array}{l}0.0188^{*} \\
(0.010)\end{array}$ & - & - & - & $\begin{array}{c}0.144 * * \\
(0.063)\end{array}$ & - & - & - \\
\hline State ownership 2 & - & $\begin{array}{c}1.203^{* * * *} \\
(0.440)\end{array}$ & - & - & - & $\begin{array}{c}0.0105^{*} \\
(0.005)\end{array}$ & - & - & - & $\begin{array}{c}0.077 * * \\
(0.036)\end{array}$ & - & - \\
\hline Controlling State & - & - & $\begin{array}{c}1.464 * * * * \\
(0.436)\end{array}$ & $\begin{array}{c}1.539 * * * \\
(0.445)\end{array}$ & - & - & $\begin{array}{c}0.0134 * * \\
(0.005)\end{array}$ & $\begin{array}{l}0.014 * * \\
(0.006)\end{array}$ & & & $\begin{array}{c}0.105 * * * \\
(0.036)\end{array}$ & $\begin{array}{l}0.099 * * \\
(0.039)\end{array}$ \\
\hline Degree of Concentration & $\begin{array}{c}0.430 \\
(0.316)\end{array}$ & - & - & - & $\begin{array}{l}0.0007 \\
(0.005)\end{array}$ & - & - & - & $\begin{array}{l}0.0492 \\
(0.043)\end{array}$ & - & - & - \\
\hline High concentration & - & $\begin{array}{c}0.026 \\
(0.171)\end{array}$ & - & - & - & $\begin{array}{l}-0.0002 \\
(0.002)\end{array}$ & - & - & & $\begin{array}{c}0.007 \\
(0.019)\end{array}$ & - & - \\
\hline Second largest & - & - & $\begin{array}{l}1.364^{*} \\
(0.717)\end{array}$ & - & - & - & $\begin{array}{c}0.006 \\
(0.012)\end{array}$ & - & - & - & $\begin{array}{l}-0.009 \\
(0.061)\end{array}$ & - \\
\hline First second & - & - & - & $\begin{array}{c}0.119 \\
(0.329)\end{array}$ & - & - & - & $\begin{array}{l}-0.0009 \\
(0.006)\end{array}$ & - & - & - & $\begin{array}{l}0.0175 \\
(0.039)\end{array}$ \\
\hline Foreign ownership 1 & $\begin{array}{l}-0.0280 \\
(0.330)\end{array}$ & - & - & - & $\begin{array}{c}0.002 \\
(0.006)\end{array}$ & - & - & - & $\begin{array}{c}0.027 \\
(0.040)\end{array}$ & - & - & - \\
\hline Foreign ownership 2 & - & $\begin{array}{l}-0.126 \\
(0.168)\end{array}$ & - & - & - & $\begin{array}{c}-0.0004 \\
(0.003)\end{array}$ & - & - & - & $\begin{array}{c}0.008 \\
(0.020)\end{array}$ & - & - \\
\hline Controlling foreign & - & - & $\begin{array}{c}0.233 \\
(0.248)\end{array}$ & $\begin{array}{c}0.195 \\
(0.252)\end{array}$ & - & - & $\begin{array}{c}0.005 \\
(0.004)\end{array}$ & $\begin{array}{c}0.004 \\
(0.005)\end{array}$ & - & - & $\begin{array}{c}0.047 \\
(0.030)\end{array}$ & $\begin{array}{c}0.045 \\
(0.031)\end{array}$ \\
\hline Board size & $\begin{array}{c}0.215 * * * \\
(0.052)\end{array}$ & $\begin{array}{c}0.222 * * * * \\
(0.052)\end{array}$ & $\begin{array}{c}0.208 * * * \\
(0.0504)\end{array}$ & $\begin{array}{c}0.215 * * * \\
(0.051)\end{array}$ & $\begin{array}{c}0.001 * \\
(0.0007)\end{array}$ & $\begin{array}{c}0.001 * \\
(0.0007)\end{array}$ & $\begin{array}{c}0.001 \\
(0.0007)\end{array}$ & $\begin{array}{c}0.001 \\
(0.0007)\end{array}$ & $\begin{array}{c}0.013 * * \\
(0.005)\end{array}$ & $\begin{array}{c}0.014 * * \\
(0.005)\end{array}$ & $\begin{array}{c}0.013 * * \\
(0.005)\end{array}$ & $\begin{array}{c}0.013 * * \\
(0.005)\end{array}$ \\
\hline Board independence & $\begin{array}{l}-0.561 \\
(0.516)\end{array}$ & $\begin{array}{l}-0.514 \\
(0.516)\end{array}$ & $\begin{array}{l}-0.507 \\
(0.503)\end{array}$ & $\begin{array}{l}-0.510 \\
(0.510)\end{array}$ & $\begin{array}{l}-0.001 \\
(0.011)\end{array}$ & $\begin{array}{c}-0.0006 \\
(0.011)\end{array}$ & $\begin{array}{l}-0.0004 \\
(0.010)\end{array}$ & $\begin{array}{l}-0.0012 \\
(0.0109)\end{array}$ & $\begin{array}{l}-0.002 \\
(0.069)\end{array}$ & $\begin{array}{l}-0.003 \\
(0.069)\end{array}$ & $\begin{array}{c}0.002 \\
(0.070)\end{array}$ & $\begin{array}{c}0.001 \\
(0.070)\end{array}$ \\
\hline Duality & $\begin{array}{l}-0.205 \\
(0.612)\end{array}$ & $\begin{array}{l}-0.537 \\
(0.666)\end{array}$ & $\begin{array}{l}-0.382 \\
(0.620)\end{array}$ & $\begin{array}{l}-0.282 \\
(0.653)\end{array}$ & $\begin{array}{l}-0.003 \\
(0.007)\end{array}$ & $\begin{array}{l}-0.008 \\
(0.005)\end{array}$ & $\begin{array}{l}-0.005 \\
(0.007)\end{array}$ & $\begin{array}{l}-0.0051 \\
(0.006)\end{array}$ & $\begin{array}{c}0.008 \\
(0.069)\end{array}$ & $\begin{array}{l}-0.008 \\
(0.074)\end{array}$ & $\begin{array}{c}0.014 \\
(0.075)\end{array}$ & $\begin{array}{c}0.016 \\
(0.075)\end{array}$ \\
\hline Group affiliation & $\begin{array}{c}0.106 \\
(0.228)\end{array}$ & $\begin{array}{c}0.080 \\
(0.230)\end{array}$ & $\begin{array}{c}0.112 \\
(0.228)\end{array}$ & $\begin{array}{c}0.092 \\
(0.228)\end{array}$ & $\begin{array}{c}0.003 \\
(0.004)\end{array}$ & $\begin{array}{c}0.003 \\
(0.003)\end{array}$ & $\begin{array}{c}0.003 \\
(0.004)\end{array}$ & $\begin{array}{c}0.003 \\
(0.004)\end{array}$ & $\begin{array}{c}0.025 \\
(0.025)\end{array}$ & $\begin{array}{c}0.021 \\
(0.024)\end{array}$ & $\begin{array}{c}0.024 \\
(0.025)\end{array}$ & $\begin{array}{c}0.024 \\
(0.025)\end{array}$ \\
\hline Size & $\begin{array}{c}0.117 * * \\
(0.054)\end{array}$ & $\begin{array}{c}0.141^{* *} \\
(0.058)\end{array}$ & $\begin{array}{c}0.110 * * \\
(0.054)\end{array}$ & $\begin{array}{l}0.124 * * \\
(0.0557)\end{array}$ & $\begin{array}{l}-0.001 \\
(0.001)\end{array}$ & $\begin{array}{l}-0.001 \\
(0.001)\end{array}$ & $\begin{array}{l}-0.001 \\
(0.001)\end{array}$ & $\begin{array}{l}-0.001 \\
(0.001)\end{array}$ & $\begin{array}{c}0.002 \\
(0.006)\end{array}$ & $\begin{array}{c}0.003 \\
(0.006)\end{array}$ & $\begin{array}{c}0.001 \\
(0.006)\end{array}$ & $\begin{array}{c}0.001 \\
(0.006)\end{array}$ \\
\hline Price to book & $\begin{array}{c}0.0891 * * \\
(0.040)\end{array}$ & $\begin{array}{l}0.081^{*} \\
(0.041)\end{array}$ & $\begin{array}{c}0.0822 * * \\
(0.0405)\end{array}$ & $\begin{array}{l}0.081 * * \\
(0.040)\end{array}$ & $\begin{array}{c}0.0029 * * * * \\
(0.0009)\end{array}$ & $\begin{array}{c}0.0029 * * * * \\
(0.0009)\end{array}$ & $\begin{array}{c}0.0029 * * * \\
(0.0009)\end{array}$ & $\begin{array}{c}0.0028 * * * \\
(0.0009)\end{array}$ & $\begin{array}{c}0.0102^{* * *} \\
(0.005)\end{array}$ & $\begin{array}{l}0.009 * \\
(0.005)\end{array}$ & $\begin{array}{c}0.0101 * * \\
(0.005)\end{array}$ & $\begin{array}{c}0.010 * * \\
(0.005)\end{array}$ \\
\hline
\end{tabular}


Table 6 (continued).

\begin{tabular}{|c|c|c|c|c|c|c|c|c|c|c|c|c|}
\hline Growth & $\begin{array}{c}-0.803^{* * *} \\
(0.183)\end{array}$ & $\begin{array}{c}-0.857 * * * \\
(0.213)\end{array}$ & $\begin{array}{c}-0.803 * * * \\
(0.192)\end{array}$ & $\begin{array}{c}-0.831^{* * * *} \\
(0.196)\end{array}$ & $\begin{array}{c}-0.014 * * * \\
(0.004)\end{array}$ & $\begin{array}{c}-0.015^{* * *} \\
(0.004)\end{array}$ & $\begin{array}{c}-0.014 * * * \\
(0.004)\end{array}$ & $\begin{array}{c}-0.015^{* * *} \\
(0.004)\end{array}$ & $\begin{array}{c}-0.066^{* * * *} \\
(0.024)\end{array}$ & $\begin{array}{c}-0.064 * * * \\
(0.024)\end{array}$ & $\begin{array}{c}-0.063 * * \\
(0.024)\end{array}$ & $\begin{array}{c}-0.063 * * * \\
(0.025)\end{array}$ \\
\hline Leverage & $\begin{array}{l}-0.484 \\
(0.366)\end{array}$ & $\begin{array}{l}-0.499 \\
(0.367)\end{array}$ & $\begin{array}{l}-0.441 \\
(0.373)\end{array}$ & $\begin{array}{l}-0.496 \\
(0.369)\end{array}$ & $\begin{array}{l}-0.003 \\
(0.008)\end{array}$ & $\begin{array}{l}-0.003 \\
(0.008)\end{array}$ & $\begin{array}{l}-0.003 \\
(0.008)\end{array}$ & $\begin{array}{l}-0.002 \\
(0.008)\end{array}$ & $\begin{array}{l}-0.045 \\
(0.035)\end{array}$ & $\begin{array}{l}-0.046 \\
(0.035)\end{array}$ & $\begin{array}{l}-0.050 \\
(0.035)\end{array}$ & $\begin{array}{l}-0.050 \\
(0.035)\end{array}$ \\
\hline Profitability & $\begin{array}{c}6.784 * * * \\
(1.506)\end{array}$ & $\begin{array}{c}6.731 * * * \\
(1.510)\end{array}$ & $\begin{array}{c}6.827 * * * \\
(1.502)\end{array}$ & $\begin{array}{c}6.749 * * * \\
(1.498)\end{array}$ & $\begin{array}{c}0.161^{* * * *} \\
(0.044)\end{array}$ & $\begin{array}{c}0.160 * * * * \\
(0.044)\end{array}$ & $\begin{array}{c}0.158^{* * * *} \\
(0.044)\end{array}$ & $\begin{array}{c}0.159^{* * * *} \\
(0.044)\end{array}$ & $\begin{array}{c}0.296^{* *} \\
(0.128)\end{array}$ & $\begin{array}{c}0.294 * * \\
(0.130)\end{array}$ & $\begin{array}{l}0.302^{* *} \\
(0.128)\end{array}$ & $\begin{array}{c}0.296^{* *} \\
(0.126)\end{array}$ \\
\hline Constant & $\begin{array}{c}-1.673 * * \\
(0.776)\end{array}$ & $\begin{array}{c}-1.725^{* *} * \\
(0.779)\end{array}$ & $\begin{array}{c}-1.613 * * \\
(0.727)\end{array}$ & $\begin{array}{c}-1.548 * * \\
(0.753)\end{array}$ & $\begin{array}{c}0.013 \\
(0.018)\end{array}$ & $\begin{array}{c}0.012 \\
(0.017)\end{array}$ & $\begin{array}{l}0.010 \\
(0.016)\end{array}$ & $\begin{array}{c}0.011 \\
(0.017)\end{array}$ & $\begin{array}{l}-0.016 \\
(0.094)\end{array}$ & $\begin{array}{l}-0.005 \\
(0.093)\end{array}$ & $\begin{array}{c}0.029 \\
(0.087)\end{array}$ & $\begin{array}{c}0.024 \\
(0.090)\end{array}$ \\
\hline $\begin{array}{l}\mathrm{R}^{2} \\
\mathrm{~F}(\text { Prob }>\mathrm{F})\end{array}$ & $\begin{array}{c}0.345 \\
10.11^{* * *}\end{array}$ & $\begin{array}{c}0.338 \\
10.7^{* * *}\end{array}$ & $\begin{array}{c}0.352 \\
11.10^{* * *}\end{array}$ & $\begin{array}{c}0.345 \\
10.82 * * *\end{array}$ & $\begin{array}{c}0.288 \\
4.65^{* * *}\end{array}$ & $\begin{array}{c}0.283 \\
4.93^{* * * *}\end{array}$ & $\begin{array}{c}0.288 \\
5.02 * * *\end{array}$ & $\begin{array}{c}0.285 \\
4.91 * * *\end{array}$ & $\begin{array}{c}0.129 \\
4.52 * * *\end{array}$ & $\begin{array}{c}0.130 \\
4.54 * * *\end{array}$ & $\begin{array}{c}0.133 \\
5.02 * * *\end{array}$ & $\begin{array}{c}0.134 \\
4.99^{* * * *}\end{array}$ \\
\hline
\end{tabular}

Notes. This table shows the results of the OLS estimations regarding the determining factors for the amount of dividend payments using data consisting 369 firms. The analyses consider the conflicts between small and large sharehol $9 * *$ heteroscedasticity-consistent standard errors are in the parentheses. * $p<0.1 ; * * p<0.05 ; * * * p<0.01$. Industry dummies are included in all models. See Table A1 for the definition of the variables. 
Table 7. Heckman regressions for the level of dividend payments: managers and shareholders conflict of interest

\begin{tabular}{|c|c|c|c|c|c|c|c|c|c|c|c|c|}
\hline \multirow[b]{3}{*}{ Family ownership 1} & \multicolumn{4}{|c|}{ Panel A. Dependent variable: DPS } & \multicolumn{4}{|c|}{ Panel B. Dependent variable: DIVTA } & \multicolumn{4}{|c|}{ Panel C. Dependent variable: DPR } \\
\hline & (1) & (2) & (3) & (4) & (5) & (6) & (7) & (8) & (9) & (10) & (11) & (12) \\
\hline & $\begin{array}{c}0.900 \\
(0.809)\end{array}$ & - & - & - & $\begin{array}{l}1.172 \\
(0.808)\end{array}$ & - & - & - & $\begin{array}{c}0.552 \\
(0.793)\end{array}$ & - & - & - \\
\hline Family ownership 2 & - & $\begin{array}{c}0.441 \\
(0.281)\end{array}$ & - & - & - & $\begin{array}{l}0.512 * \\
(0.276)\end{array}$ & - & - & - & $\begin{array}{c}0.280 \\
(0.286)\end{array}$ & - & - \\
\hline Family ownership 3 & - & - & $\begin{array}{c}0.266 \\
(0.357)\end{array}$ & - & - & - & $\begin{array}{c}0.426 \\
(0.359)\end{array}$ & - & - & - & $\begin{array}{c}0.118 \\
(0.357)\end{array}$ & - \\
\hline Controlling family & - & - & - & $\begin{array}{l}0.0284 \\
(0.313)\end{array}$ & - & - & - & $\begin{array}{c}0.101 \\
(0.307)\end{array}$ & - & - & - & $\begin{array}{l}-0.113 \\
(0.313)\end{array}$ \\
\hline State ownership 1 & $\begin{array}{c}0.368 \\
(0.736)\end{array}$ & - & - & - & $\begin{array}{c}0.161 \\
(0.740)\end{array}$ & - & - & - & $\begin{array}{c}0.334 \\
(0.722)\end{array}$ & - & - & - \\
\hline State ownership 2 & - & $\begin{array}{c}0.148 \\
(0.427)\end{array}$ & - & - & - & $\begin{array}{l}0.0315 \\
(0.431)\end{array}$ & - & - & - & $\begin{array}{c}0.113 \\
(0.421)\end{array}$ & - & - \\
\hline Controlling State & - & - & $\begin{array}{c}0.391 \\
(0.492)\end{array}$ & $\begin{array}{c}0.390 \\
(0.492)\end{array}$ & - & - & $\begin{array}{c}0.257 \\
(0.493)\end{array}$ & $\begin{array}{c}0.251 \\
(0.493)\end{array}$ & - & - & $\begin{array}{c}0.358 \\
(0.483)\end{array}$ & $\begin{array}{c}0.343 \\
(0.483)\end{array}$ \\
\hline Agency conflict & $\begin{array}{c}-0.158 * * * \\
(0.040)\end{array}$ & $\begin{array}{c}-0.153 * * * \\
(0.039)\end{array}$ & $\begin{array}{c}-0.157 * * * \\
(0.040)\end{array}$ & $\begin{array}{c}-0.157 * * * \\
(0.040)\end{array}$ & $\begin{array}{c}-0.163 * * * * \\
(0.0404)\end{array}$ & $\begin{array}{c}-0.160 * * * \\
(0.0397)\end{array}$ & $\begin{array}{c}-0.164 * * * \\
(0.0407)\end{array}$ & $\begin{array}{c}-0.163 * * * \\
(0.0406)\end{array}$ & $\begin{array}{c}-0.164 * * * \\
(0.041)\end{array}$ & $\begin{array}{c}-0.161 * * * * \\
(0.040)\end{array}$ & $\begin{array}{c}-0.164 * * * * \\
(0.041)\end{array}$ & $\begin{array}{c}-0.165 * * * \\
(0.041)\end{array}$ \\
\hline Foreign ownership 1 & $\begin{array}{l}-0.237 \\
(0.311)\end{array}$ & $\begin{array}{l}- \\
-\end{array}$ & - & - & $\begin{array}{l}-0.305 \\
(0.310)\end{array}$ & - & - & - & $\begin{array}{l}-0.251 \\
(0.311)\end{array}$ & - & - & - \\
\hline Foreign ownership 2 & - & $\begin{array}{l}-0.097 \\
(0.168)\end{array}$ & - & - & - & $\begin{array}{l}-0.138 \\
(0.168)\end{array}$ & - & - & - & $\begin{array}{l}-0.121 \\
(0.166)\end{array}$ & - & - \\
\hline Controlling foreign & - & $\begin{array}{l}- \\
-\end{array}$ & $\begin{array}{l}-0.127 \\
(0.219)\end{array}$ & $\begin{array}{l}-0.110 \\
(0.220)\end{array}$ & - & - & $\begin{array}{l}-0.180 \\
(0.221)\end{array}$ & $\begin{array}{l}-0.158 \\
(0.221)\end{array}$ & - & - & $\begin{array}{l}-0.124 \\
(0.218)\end{array}$ & $\begin{array}{l}-0.133 \\
(0.220)\end{array}$ \\
\hline Board size & $\begin{array}{c}0.139 * * \\
(0.055)\end{array}$ & $\begin{array}{c}0.133 * * \\
(0.055)\end{array}$ & $\begin{array}{c}0.136 * * \\
(0.055)\end{array}$ & $\begin{array}{c}0.140 * * \\
(0.054)\end{array}$ & $\begin{array}{l}0.132 * * \\
(0.0550)\end{array}$ & $\begin{array}{l}0.129 * * \\
(0.0548)\end{array}$ & $\begin{array}{l}0.129 * * \\
(0.0552)\end{array}$ & $\begin{array}{l}0.134 * * \\
(0.0547)\end{array}$ & $\begin{array}{c}0.136 * * \\
(0.053)\end{array}$ & $\begin{array}{c}0.134 * * \\
(0.053)\end{array}$ & $\begin{array}{l}0.134 * * \\
(0.053)\end{array}$ & $\begin{array}{l}0.136 * * \\
(0.053)\end{array}$ \\
\hline Board independence & $\begin{array}{l}-0.867 \\
(0.578)\end{array}$ & $\begin{array}{l}-0.907 \\
(0.576)\end{array}$ & $\begin{array}{l}-0.880 \\
(0.578)\end{array}$ & $\begin{array}{l}-0.885 \\
(0.579)\end{array}$ & $\begin{array}{l}-0.974^{*} \\
(0.577)\end{array}$ & $\begin{array}{c}-0.995^{*} \\
(0.572)\end{array}$ & $\begin{array}{c}-0.973 * \\
(0.578)\end{array}$ & $\begin{array}{c}-0.988^{*} \\
(0.579)\end{array}$ & $\begin{array}{l}-0.971^{*} \\
(0.581)\end{array}$ & $\begin{array}{l}-0.962^{*} \\
(0.576)\end{array}$ & $\begin{array}{c}-0.984 * \\
(0.580)\end{array}$ & $\begin{array}{l}-1.014 * \\
(0.582)\end{array}$ \\
\hline Duality & $\begin{array}{l}-0.198 \\
(0.571)\end{array}$ & $\begin{array}{l}-0.164 \\
(0.555)\end{array}$ & $\begin{array}{l}-0.075 \\
(0.547)\end{array}$ & $\begin{array}{l}0.0175 \\
(0.553)\end{array}$ & $\begin{array}{l}-0.317 \\
(0.580)\end{array}$ & $\begin{array}{l}-0.277 \\
(0.551)\end{array}$ & $\begin{array}{l}-0.182 \\
(0.550)\end{array}$ & $\begin{array}{l}-0.0640 \\
(0.553)\end{array}$ & $\begin{array}{l}-0.132 \\
(0.566)\end{array}$ & $\begin{array}{l}-0.135 \\
(0.554)\end{array}$ & $\begin{array}{c}-0.0281 \\
(0.548)\end{array}$ & $\begin{array}{l}0.0835 \\
(0.556)\end{array}$ \\
\hline Group affiliation & $\begin{array}{c}0.186 \\
(0.200)\end{array}$ & $\begin{array}{c}0.186 \\
(0.199)\end{array}$ & $\begin{array}{c}0.193 \\
(0.198)\end{array}$ & $\begin{array}{c}0.193 \\
(0.198)\end{array}$ & $\begin{array}{c}0.184 \\
(0.199)\end{array}$ & $\begin{array}{c}0.184 \\
(0.198)\end{array}$ & $\begin{array}{c}0.191 \\
(0.197)\end{array}$ & $\begin{array}{c}0.190 \\
(0.197)\end{array}$ & $\begin{array}{c}0.197 \\
(0.199)\end{array}$ & $\begin{array}{c}0.203 \\
(0.197)\end{array}$ & $\begin{array}{c}0.213 \\
(0.197)\end{array}$ & $\begin{array}{c}0.215 \\
(0.197)\end{array}$ \\
\hline Size & $\begin{array}{c}0.175^{* * *} \\
(0.066)\end{array}$ & $\begin{array}{c}0.185^{* * * *} \\
(0.066)\end{array}$ & $\begin{array}{c}0.163^{* *} \\
(0.066)\end{array}$ & $\begin{array}{c}0.154 * * \\
(0.065)\end{array}$ & $\begin{array}{c}0.188^{* * *} \\
(0.0670)\end{array}$ & $\begin{array}{c}0.196^{* * *} \\
(0.0667)\end{array}$ & $\begin{array}{c}0.177 * * * \\
(0.0670)\end{array}$ & $\begin{array}{l}0.165 * * \\
(0.0657)\end{array}$ & $\begin{array}{c}0.178 * * * \\
(0.066)\end{array}$ & $\begin{array}{c}0.183 * * * \\
(0.066)\end{array}$ & $\begin{array}{c}0.166^{* *} \\
(0.066)\end{array}$ & $\begin{array}{c}0.159^{* * *} \\
(0.065)\end{array}$ \\
\hline Price to Book & $\begin{array}{c}0.113 * * * \\
(0.039)\end{array}$ & $\begin{array}{c}0.118 * * * \\
(0.038)\end{array}$ & $\begin{array}{c}0.118^{* * * *} \\
(0.039)\end{array}$ & $\begin{array}{c}0.124 * * * \\
(0.0389)\end{array}$ & $\begin{array}{c}0.115^{* * *} \\
(0.0404)\end{array}$ & $\begin{array}{c}0.122 * * * \\
(0.0393)\end{array}$ & $\begin{array}{c}0.120 * * * \\
(0.0397)\end{array}$ & $\begin{array}{c}0.128 * * * \\
(0.0396)\end{array}$ & $\begin{array}{c}0.129 * * * \\
(0.040)\end{array}$ & $\begin{array}{c}0.133 * * * \\
(0.038)\end{array}$ & $\begin{array}{c}0.133 * * * \\
(0.039)\end{array}$ & $\begin{array}{c}0.140 * * * \\
(0.038)\end{array}$ \\
\hline Growth & $\begin{array}{c}-0.781 * * \\
(0.385)\end{array}$ & $\begin{array}{c}-0.730^{*} \\
(0.375)\end{array}$ & $\begin{array}{c}-0.736^{*} \\
(0.377)\end{array}$ & $\begin{array}{l}-0.711^{*} \\
(0.372)\end{array}$ & $\begin{array}{c}-0.749 * * \\
(0.374)\end{array}$ & $\begin{array}{l}-0.700^{*} \\
(0.364)\end{array}$ & $\begin{array}{c}-0.708^{*} \\
(0.366)\end{array}$ & $\begin{array}{l}-0.665^{*} \\
(0.359)\end{array}$ & $\begin{array}{c}-0.859^{* *} \\
(0.395)\end{array}$ & $\begin{array}{c}-0.860^{* *} \\
(0.397)\end{array}$ & $\begin{array}{c}-0.826^{* *} \\
(0.390)\end{array}$ & $\begin{array}{c}-0.820^{* *} \\
(0.388)\end{array}$ \\
\hline Leverage & $\begin{array}{c}-0.961 * * \\
(0.429)\end{array}$ & $\begin{array}{c}-0.921 * * \\
(0.424)\end{array}$ & $\begin{array}{c}-0.943 * * \\
(0.428)\end{array}$ & $\begin{array}{c}-0.943 * * \\
(0.427)\end{array}$ & $\begin{array}{c}-1.048^{* * *} \\
(0.430)\end{array}$ & $\begin{array}{c}-1.001 * * \\
(0.424)\end{array}$ & $\begin{array}{c}-1.030 * * \\
(0.430)\end{array}$ & $\begin{array}{c}-1.034 * * \\
(0.429)\end{array}$ & $\begin{array}{c}-1.057 * * \\
(0.436)\end{array}$ & $\begin{array}{c}-0.999 * * \\
(0.431)\end{array}$ & $\begin{array}{c}-1.028^{* * *} \\
(0.432)\end{array}$ & $\begin{array}{c}-1.040^{* * *} \\
(0.432)\end{array}$ \\
\hline Profitability & $\begin{array}{c}8.508^{* * * * *} \\
(1.550)\end{array}$ & $\begin{array}{c}8.601 * * * \\
(1.543)\end{array}$ & $\begin{array}{c}8.481 * * * \\
(1.547)\end{array}$ & $\begin{array}{c}8.359^{* * * *} \\
(1.528)\end{array}$ & $\begin{array}{c}8.807 * * * \\
(1.513)\end{array}$ & $\begin{array}{c}8.862^{* * * *} \\
(1.497)\end{array}$ & $\begin{array}{c}8.719^{* * * *} \\
(1.514)\end{array}$ & $\begin{array}{c}8.576^{* * * *} \\
(1.487)\end{array}$ & $\begin{array}{c}8.871 * * * \\
(1.586)\end{array}$ & $\begin{array}{c}8.928 * * * \\
(1.573)\end{array}$ & $\begin{array}{c}8.836^{* * * *} \\
(1.577)\end{array}$ & $\begin{array}{c}8.791 * * * \\
(1.563)\end{array}$ \\
\hline Constant & $\begin{array}{c}-2.553^{* * *} * \\
(0.834)\end{array}$ & $\begin{array}{c}-2.724 * * * \\
(0.824)\end{array}$ & $\begin{array}{c}-2.417 * * * \\
(0.818)\end{array}$ & $\begin{array}{c}-2.312^{* * * *} \\
(0.819)\end{array}$ & $\begin{array}{c}-2.631 * * * \\
(0.837)\end{array}$ & $\begin{array}{c}-2.776^{* * * *} \\
(0.829)\end{array}$ & $\begin{array}{c}-2.507 * * * * \\
(0.823)\end{array}$ & $\begin{array}{c}-2.358 * * * \\
(0.821)\end{array}$ & $\begin{array}{c}-2.505^{* * * *} \\
(0.832)\end{array}$ & $\begin{array}{c}-2.617 * * * \\
(0.819)\end{array}$ & $\begin{array}{c}-2.378^{* * * *} \\
(0.819)\end{array}$ & $\begin{array}{c}-2.256^{* * * *} \\
(0.822)\end{array}$ \\
\hline
\end{tabular}


Table 7 (continued).

\begin{tabular}{|c|c|c|c|c|c|c|c|c|c|c|c|c|}
\hline Wald $\chi^{2}$ & 55.48 & 47.91 & 53.61 & 53.38 & 111.49 & 108.10 & 113.5 & 107.88 & 31.85 & 30.94 & 34.27 & 34.49 \\
\hline Mills Lambda (Coefficient) & -0.109 & -0.233 & -0.125 & -0.128 & -0.013 & -0.014 & -0.102 & -0.013 & 0.072 & 0.083 & 0.071 & 0.076 \\
\hline Prob Mills Lambda $>\chi^{2}$ & 0.607 & 0.342 & 0.559 & 0.566 & 0.064 & 0.035 & 0.092 & 0.102 & 0.126 & 0.135 & 0.117 & 0.084 \\
\hline
\end{tabular}


Table 8. Heckman regressions for the level of dividend payments: Major-minor shareholders conflicts of interest

\begin{tabular}{|c|c|c|c|c|c|c|c|c|c|c|c|c|}
\hline \multirow[b]{3}{*}{ Family ownership 1} & \multicolumn{4}{|c|}{ Panel A. Dependent variable: DPS } & \multicolumn{4}{|c|}{ Panel B. Dependent variable: DIVTA } & \multicolumn{4}{|c|}{ Panel C. Dependent variable: DPR } \\
\hline & (1) & (2) & (3) & (4) & (5) & (6) & $(7)$ & (8) & (9) & (10) & (11) & (12) \\
\hline & $\begin{array}{l}-0.322 \\
(0.728)\end{array}$ & - & - & - & $\begin{array}{c}-0.0747 * * \\
(0.0295)\end{array}$ & - & - & - & $\begin{array}{c}0.256 \\
(0.712)\end{array}$ & - & - & - \\
\hline Family ownership 2 & & $\begin{array}{c}0.232 \\
(0.261)\end{array}$ & - & - & - & $\begin{array}{c}-0.0152 \\
(0.0102)\end{array}$ & - & - & - & $\begin{array}{c}0.273 \\
(0.262)\end{array}$ & - & - \\
\hline Family ownership 3 & - & - & $\begin{array}{l}-0.137 \\
(0.335)\end{array}$ & - & - & - & $\begin{array}{c}-0.0313 * * * * \\
(0.0116)\end{array}$ & - & - & - & $\begin{array}{l}0.0198 \\
(0.330)\end{array}$ & \\
\hline Controlling family & - & - & - & $\begin{array}{l}-0.0816 \\
(0.298)\end{array}$ & - & - & - & $\begin{array}{c}-0.0265 * * \\
(0.0121)\end{array}$ & - & - & - & $\begin{array}{l}0.0219 \\
(0.293)\end{array}$ \\
\hline State ownership 1 & $\begin{array}{l}1.159^{*} \\
(0.703)\end{array}$ & - & - & - & $\begin{array}{c}0.0366 \\
(0.0228)\end{array}$ & - & - & - & $\begin{array}{c}0.890 \\
(0.692)\end{array}$ & - & - & - \\
\hline State ownership 2 & & $\begin{array}{c}0.625 \\
(0.400)\end{array}$ & - & - & - & $\begin{array}{c}0.0191 \\
(0.0128)\end{array}$ & - & - & - & $\begin{array}{c}0.424 \\
(0.399)\end{array}$ & & \\
\hline Controlling State & - & - & $\begin{array}{l}0.913^{*} \\
(0.469)\end{array}$ & $\begin{array}{c}0.932 * * \\
(0.473)\end{array}$ & - & - & $\begin{array}{c}0.0211 \\
(0.0131)\end{array}$ & $\begin{array}{l}0.0266^{*} \\
(0.0154)\end{array}$ & - & - & $\begin{array}{l}0.779 * \\
(0.463)\end{array}$ & $\begin{array}{c}0.704 \\
(0.471)\end{array}$ \\
\hline Degree of concentration & $\begin{array}{c}0.116 \\
(0.317)\end{array}$ & - & - & - & $\begin{array}{c}0.0046 \\
(0.0116)\end{array}$ & - & - & - & $\begin{array}{c}0.300 \\
(0.374)\end{array}$ & - & - & - \\
\hline High concentration & & $\begin{array}{c}-0.0019 \\
(0.156)\end{array}$ & - & - & - & $\begin{array}{c}0.0003 \\
(0.0054)\end{array}$ & - & - & - & $\begin{array}{c}0.108 \\
(0.155)\end{array}$ & - & - \\
\hline Second largest & - & - & $\begin{array}{c}0.728 \\
(0.660)\end{array}$ & - & - & - & $\begin{array}{c}0.0222 \\
(0.0212)\end{array}$ & - & - & - & $\begin{array}{c}0.109 \\
(0.532)\end{array}$ & - \\
\hline First second & - & - & - & $\begin{array}{l}0.0180 \\
(0.285)\end{array}$ & - & - & - & $\begin{array}{c}-0.0062 \\
(0.0096)\end{array}$ & - & - & - & $\begin{array}{c}0.233 \\
(0.282)\end{array}$ \\
\hline Foreign ownership 1 & $\begin{array}{l}0.0392 \\
(0.289)\end{array}$ & - & - & - & $\begin{array}{c}0.0072 \\
(0.0110)\end{array}$ & - & - & - & $\begin{array}{l}0.0329 \\
(0.296)\end{array}$ & - & - & - \\
\hline Foreign ownership 2 & & $\begin{array}{l}0.0142 \\
(0.153)\end{array}$ & - & - & - & $\begin{array}{c}0.00119 \\
(0.00579)\end{array}$ & - & - & - & $\begin{array}{l}-0.0199 \\
(0.154)\end{array}$ & - & - \\
\hline Controlling foreign & - & - & $\begin{array}{c}0.231 \\
(0.203)\end{array}$ & $\begin{array}{c}0.215 \\
(0.206)\end{array}$ & - & - & $\begin{array}{c}0.0115 \\
(0.0073)\end{array}$ & $\begin{array}{c}0.0102 \\
(0.0083)\end{array}$ & - & . & $\begin{array}{c}0.198 \\
(0.205)\end{array}$ & $\begin{array}{c}0.178 \\
(0.208)\end{array}$ \\
\hline Board size & $\begin{array}{c}0.141 * * * \\
(0.0489)\end{array}$ & $\begin{array}{c}0.142 * * * \\
(0.0489)\end{array}$ & $\begin{array}{c}0.136^{* * * *} \\
(0.0488)\end{array}$ & $\begin{array}{c}0.139 * * * \\
(0.0485)\end{array}$ & $\begin{array}{c}0.0031 \\
(0.0031)\end{array}$ & $\begin{array}{c}0.0025 \\
(0.0030)\end{array}$ & $\begin{array}{c}0.0013 \\
(0.0027)\end{array}$ & $\begin{array}{c}0.0031 \\
(0.0031)\end{array}$ & $\begin{array}{c}0.179 * * * \\
(0.0514)\end{array}$ & $\begin{array}{c}0.180 * * * \\
(0.0513)\end{array}$ & $\begin{array}{c}0.181 * * * \\
(0.0510)\end{array}$ & $\begin{array}{c}0.180 * * * \\
(0.0509)\end{array}$ \\
\hline Board independence & $\begin{array}{l}-0.526 \\
(0.494)\end{array}$ & $\begin{array}{l}-0.544 \\
(0.494)\end{array}$ & $\begin{array}{l}-0.491 \\
(0.494)\end{array}$ & $\begin{array}{l}-0.499 \\
(0.495)\end{array}$ & $\begin{array}{l}-0.0106 \\
(0.0210)\end{array}$ & $\begin{array}{l}-0.0087 \\
(0.0207)\end{array}$ & $\begin{array}{l}-0.0039 \\
(0.0196)\end{array}$ & $\begin{array}{l}-0.0126 \\
(0.0217)\end{array}$ & $\begin{array}{l}-0.498 \\
(0.492)\end{array}$ & $\begin{array}{l}-0.516 \\
(0.490)\end{array}$ & $\begin{array}{l}-0.468 \\
(0.490)\end{array}$ & $\begin{array}{l}-0.461 \\
(0.491)\end{array}$ \\
\hline Duality & $\begin{array}{c}0.477 \\
(0.563)\end{array}$ & $\begin{array}{c}0.300 \\
(0.559)\end{array}$ & $\begin{array}{c}0.470 \\
(0.557)\end{array}$ & $\begin{array}{c}0.491 \\
(0.568)\end{array}$ & $\begin{array}{c}0.0340 \\
(0.0250)\end{array}$ & $\begin{array}{c}0.0072 \\
(0.0220)\end{array}$ & $\begin{array}{c}0.0179 \\
(0.0216)\end{array}$ & $\begin{array}{c}0.0187 \\
(0.0240)\end{array}$ & $\begin{array}{c}0.281 \\
(0.577)\end{array}$ & $\begin{array}{c}0.198 \\
(0.570)\end{array}$ & $\begin{array}{c}0.345 \\
(0.561)\end{array}$ & $\begin{array}{c}0.324 \\
(0.575)\end{array}$ \\
\hline Group affiliation & $\begin{array}{l}0.208 \\
(0.184)\end{array}$ & $\begin{array}{c}0.203 \\
(0.183)\end{array}$ & $\begin{array}{c}0.224 \\
(0.184)\end{array}$ & $\begin{array}{c}0.210 \\
(0.183)\end{array}$ & $\begin{array}{c}0.0016 \\
(0.0078)\end{array}$ & $\begin{array}{c}-0.0006 \\
(0.0075)\end{array}$ & $\begin{array}{l}-0.0010 \\
(0.0072)\end{array}$ & $\begin{array}{l}-0.0003 \\
(0.0079)\end{array}$ & $\begin{array}{c}0.228 \\
(0.185)\end{array}$ & $\begin{array}{c}0.217 \\
(0.184)\end{array}$ & $\begin{array}{c}0.230 \\
(0.184)\end{array}$ & $\begin{array}{c}0.227 \\
(0.184)\end{array}$ \\
\hline Size & $\begin{array}{l}0.128 * * \\
(0.0588)\end{array}$ & $\begin{array}{l}0.149 * * \\
(0.0595)\end{array}$ & $\begin{array}{l}0.120^{* * *} \\
(0.0587)\end{array}$ & $\begin{array}{l}0.130 * * \\
(0.0586)\end{array}$ & $\begin{array}{l}-0.0038 \\
(0.0027)\end{array}$ & $\begin{array}{l}-0.0034 \\
(0.0027)\end{array}$ & $\begin{array}{l}-0.0039 \\
(0.0024)\end{array}$ & $\begin{array}{l}-0.0031 \\
(0.0027)\end{array}$ & $\begin{array}{c}0.103 * \\
(0.0591)\end{array}$ & $\begin{array}{c}0.113^{*} \\
(0.0590)\end{array}$ & $\begin{array}{c}0.0889 \\
(0.0585)\end{array}$ & $\begin{array}{c}0.0945 \\
(0.0580)\end{array}$ \\
\hline Price to book & $\begin{array}{l}0.0674 * \\
(0.0351)\end{array}$ & $\begin{array}{l}0.0624 * \\
(0.0344)\end{array}$ & $\begin{array}{l}0.0670^{*} \\
(0.0350)\end{array}$ & $\begin{array}{l}0.0653^{*} \\
(0.0346)\end{array}$ & $\begin{array}{c}0.0059^{* * * *} \\
(0.0018)\end{array}$ & $\begin{array}{c}0.0047 * * * * \\
(0.0017)\end{array}$ & $\begin{array}{c}0.0047 * * * \\
(0.0016)\end{array}$ & $\begin{array}{c}0.0055^{* * * *} \\
(0.0018)\end{array}$ & $\begin{array}{c}0.0736 * * \\
(0.0350)\end{array}$ & $\begin{array}{c}0.0719 * * \\
(0.0345)\end{array}$ & $\begin{array}{c}0.0732 * * \\
(0.0348)\end{array}$ & $\begin{array}{c}0.0738^{* * *} \\
(0.0345)\end{array}$ \\
\hline
\end{tabular}


Table 8 (continued)

\begin{tabular}{|c|c|c|c|c|c|c|c|c|c|c|c|c|}
\hline Growth & $\begin{array}{c}-0.831^{* *} \\
(0.329)\end{array}$ & $\begin{array}{c}-0.897 * * * \\
(0.331)\end{array}$ & $\begin{array}{c}-0.825^{* *} \\
(0.328)\end{array}$ & $\begin{array}{c}-0.855^{* * * *} \\
(0.327)\end{array}$ & $\begin{array}{c}-0.0487 * * \\
(0.0209)\end{array}$ & $\begin{array}{c}-0.0468 * * \\
(0.0210)\end{array}$ & $\begin{array}{c}-0.0382 * * \\
(0.0187)\end{array}$ & $\begin{array}{c}-0.0519 * * \\
(0.0209)\end{array}$ & $\begin{array}{c}-0.931 * * * \\
(0.322)\end{array}$ & $\begin{array}{c}-0.926 * * * \\
(0.319)\end{array}$ & $\begin{array}{c}-0.904 * * * \\
(0.317)\end{array}$ & $\begin{array}{c}-0.902 * * * \\
(0.315)\end{array}$ \\
\hline Leverage & $\begin{array}{l}-0.574^{*} \\
(0.349)\end{array}$ & $\begin{array}{c}-0.597^{*} \\
(0.348)\end{array}$ & $\begin{array}{l}-0.548 \\
(0.348)\end{array}$ & $\begin{array}{l}-0.582^{*} \\
(0.346)\end{array}$ & $\begin{array}{l}-0.0118 \\
(0.0198)\end{array}$ & $\begin{array}{l}-0.0069 \\
(0.0194)\end{array}$ & $\begin{array}{l}-0.0039 \\
(0.0179)\end{array}$ & $\begin{array}{l}-0.0120 \\
(0.0203)\end{array}$ & $\begin{array}{l}-0.620^{*} \\
(0.345)\end{array}$ & $\begin{array}{c}-0.633^{*} \\
(0.345)\end{array}$ & $\begin{array}{l}-0.632^{*} \\
(0.345)\end{array}$ & $\begin{array}{l}-0.639^{*} \\
(0.343)\end{array}$ \\
\hline Profitability & $\begin{array}{c}6.548 * * * \\
(1.197)\end{array}$ & $\begin{array}{c}6.566 * * * \\
(1.197)\end{array}$ & $\begin{array}{c}6.649 * * * \\
(1.193)\end{array}$ & $\begin{array}{c}6.605^{* * *} \\
(1.205)\end{array}$ & $\begin{array}{c}0.358 * * * \\
(0.0738)\end{array}$ & $\begin{array}{c}0.353 * * * \\
(0.0722)\end{array}$ & $\begin{array}{c}0.340^{* * *} \\
(0.0644)\end{array}$ & $\begin{array}{c}0.373 * * * \\
(0.0765)\end{array}$ & $\begin{array}{c}6.379 * * * \\
(1.195)\end{array}$ & $\begin{array}{c}6.411 * * * \\
(1.192)\end{array}$ & $\begin{array}{c}6.539 * * * \\
(1.194)\end{array}$ & $\begin{array}{c}6.391 * * * \\
(1.200)\end{array}$ \\
\hline Constant & $\begin{array}{c}-2.733 * * * \\
(0.812)\end{array}$ & $\begin{array}{c}-2.934 * * * \\
(0.801)\end{array}$ & $\begin{array}{c}-2.735^{* * *} * \\
(0.770)\end{array}$ & $\begin{array}{c}-2.702 * * * \\
(0.787)\end{array}$ & $\begin{array}{c}0.0209 \\
(0.0585)\end{array}$ & $\begin{array}{c}0.0256 \\
(0.0593)\end{array}$ & $\begin{array}{c}0.0408 \\
(0.0511)\end{array}$ & $\begin{array}{c}0.0122 \\
(0.0588)\end{array}$ & $\begin{array}{l}-0.156 \\
(0.478)\end{array}$ & $\begin{array}{c}-2.528 * * * \\
(0.790)\end{array}$ & $\begin{array}{c}-2.204 * * * \\
(0.760)\end{array}$ & $\begin{array}{c}-2.322 * * * \\
(0.780)\end{array}$ \\
\hline Wald $\chi^{2}$ & 37.92 & 36.18 & 38.74 & 36.69 & 70.70 & 74.38 & 78.09 & 71.83 & 15.67 & 19.63 & 20.39 & 19.18 \\
\hline Mills Lambda (Coefficient) & 0.0633 & -0.409 & -0.585 & -0.0827 & 0.0340 & 0.0276 & 0.0187 & 0.0375 & 0.299 & 0.275 & 0.266 & 0.276 \\
\hline Prob Mills Lambda $>\chi^{2}$ & 0.904 & 0.796 & 0.921 & 0.985 & 0.144 & 0.209 & 0.176 & 0.140 & 0.118 & 0.113 & 0.107 & 0.106 \\
\hline
\end{tabular}

Notes. This table presents the results of Heckman regression for the level of dividend payments from data consisting 369 firms. The analyses consider the conflicts between small and large shareholders. Panel A, Panel B, and Panel C use different dependent
variables; they are DPS, DIVTA and DPR, respectively. Each panel has four model specification based on selected independent variables. Robust heteroscedasticity-consistent standard errors are in the parentheses. * $p<0.1 ; * * 0<0.05 ; * * * p<0.01$. Industry dummies are included in all models. See Table A1 for the definition of the variables. 